Benavides Vanegas, Farid Samir,

“El archivo y el testigo. Un análisis de la relación entre memoria y justicia a partir del caso colombiano", Nuevo Foro Penal, 92, (2019)

\title{
El archivo y el testigo. Un análisis de la relación entre memoria y justicia a partir del caso colombiano*
}

The file and the witness. Analysis of the relation between memory and justice from the colombian case

\author{
Farid Samir Benavides Vanegas* \\ Fecha de recepción: 29/01/2019 - Fecha de aceptación: 09/04/2019
}

DOI 10.17230/NFP.15.92.3

\section{Resumen}

En los estudios de la memoria y de la justicia transicional se suele dar relevancia al relato de las víctimas. Se suele asumir, que lo dicho por las víctimas tiene un valor absoluto de verdad y que no puede ser controvertido, pues de lo contrario estaríamos atentando contra su dignidad. Y, al lado de esto, se afirma que todo lo sostenido por los perpetradores es falso, y por tanto no podemos creer absolutamente en lo que ellos relatan. Lo curioso es que ni perpetrador ni víctimas son testigos, sino que, desde un punto de vista jurídico, son partes activas en esa relación social que se llama delito.

En este texto, quiero discutir la relación entre el testigo y el archivo y para ello me valgo del caso colombiano como un caso de estudio. Inicialmente analizo la cuestión de la memoria y posteriormente me ocupo de analizar las relaciones entre verdad y memoria. Con este texto, pretendo hacer un aporte a los estudios de justicia transicional que dan

* Profesor asociado PhD. Facultad de Comunicación y Relaciones Internacionales Universidad Ramón Llull - Blanquerna, Barcelona. Contacto: faridsamirbv@blanquerna.url.edu

* Este texto fue originalmente presentado en el Congreso de la Latin American Studies Association. Barcelona, 23 - 26 de mayo de 2018. Este capítulo se basa en un texto más amplio sobre Verdad Judicial y Memoria en Colombia, que está próximo a publicarse. 
106 El archivo y el testigo. Un análisis de la relación entre memoria y justicia a partir del caso colombiano -

Farid Samir Benavides Vanegas

por sentada, sin más, la validez de los aportes documentales o de los relatos de las víctimas y de los testigos. No se trata de una mera pretensión teórica, pues de ello depende la elaboración de criterios de verdad tanto para el juicio penal como para las Comisiones de la Verdad.

\section{Abstract}

In memory studies and in the field of transitional justice, the story of the victims is usually seen as relevant. It is usually assumed that what is said by the victims has an absolute value of truth and cannot be controverted, otherwise we would be attacking their dignity. And, next to this, it is maintained that everything held by the perpetrators is false, and therefore we cannot believe absolutely in what they tell. But we have to take into account that neither perpetrator nor victims are witnesses, but, from a legal point of view, they are active parties in that social relationship we call crime.

In this text, I want to discuss the relationship between the witness and the archive and for that I use the Colombian case as a case study. Initially I analyze the question of memory and later on I analyze the relationships between truth and memory. With this text, I intend to contribute to the studies of transitional justice that take for granted, without further analysis, the validity of the documentary contributions or the stories of the victims and the witnesses. It is not a mere theoretical pretension, since it depends on the elaboration of truth criteria for both the criminal justice system and the Truth Commissions.

\section{Palabras clave}

Justicia transicional, proceso penal, Comisiones de la Verdad, verdad histórica, verdad judicial, memoria.

\section{Keywords}

Transitional justice, criminal process, Truth Commissions, historical truth, judicial truth, memory.

\section{Sumario}

1. Introducción. 2. La memoria como un deber; 3. La verdad en el proceso judicial; 4. La verdad, el testigo y la memoria; 5. Memoria y verdad; $\mathbf{6}$. La confesión judicial y la memoria; 7. Testimonios perturbadores; 8. Conclusión: ¿testimonios perturbadores y archivos tranquilizadores? Bibliografía. 


\section{Introducción}

La justicia transicional se ha convertido en un elemento central en los procesos de transición contemporáneos, especialmente en aquellos en los que se hace un tránsito del conflicto al postconflicto. ${ }^{1}$ Más allá de las críticas en contra de este campo, algunas de las cuales comparto y sobre las que he escrito en otro contexto ${ }^{2}$ los mecanismos de justicia transicional se han convertido en un elemento fundamental de la paz negativa, cuando se utiliza como un elemento para invitar a los actores a tomar parte de las negociaciones; 0 de la paz positiva, cuando se convierte en un elemento central del jus pos bellum o de la construcción de paz. ${ }^{3}$

Los mecanismos clásicos de la justicia transicional se han concentrado en la justicia retributiva, particularmente penal; en las Comisiones de la Verdad; y en los mecanismos de reparación; todos ellos con miras a obtener y realizar las garantías de no repetición. Sin embargo, de manera reciente, se ha discutido el papel de la memoria en los procesos de transición. Y dentro de estos estudios de la memoria ha cobrado relevancia la figura del testigo. ${ }^{4}$ De éste se dice que aporta a la verdad, pero con frecuencia se confunde la categoría del testigo con la de la víctima, pasando por alto que el testigo es un tercero que da cuenta de un acto que ha presenciado. El tratamiento del testigo es diferente dependiendo de si se trata de un proceso penal, de una Comisión de la Verdad o de los estudios de la memoria. Las exigencias derivadas de las pretensiones de verdad también varían, pues los criterios del proceso penal suelen ser más estrictos que los de los otros campos. Y, sin embargo, todos ellos hablan de la verdad. Frente al testigo se opone el archivo documental, sobre la base de que el documento documenta la verdad, y por tanto está más allá de toda duda. ${ }^{5}$

1 Arthur, Palge. «How 'Transitions' Reshaped Human Rights: A Conceptual History of Transitional Justice.» Human Rights Quarterly 31, 2009: 321 - 367.

2 Benavides, Farid. «iTiene futuro la justicia transicional?» Revista Derecho Penal No. 58, 2017: 5 - 44.

3 Bass, Gary J. "Jus Post Bellum.» Philosophy and Public Affairs 32 (4), 2004: 384 - 412. Benavides, Farid, Blanca Camps, y Oscar Mateos. «Los retos de la Justicia Transicional en las nuevas transiciones: un estado de la cuestión a partir de los casos de Colombia, Marruecos y Sierra Leona.» Revista de Relaciones Internacionales de la UAM No. 38, 2018.

4 Aller Montaño, Eugenia; Crenzel, Emilio (eds). Las luchas por la memoria en América Latina. Historia reciente y violencia política. Madrid: Iberoamericana, 2016.

5 Robien, Antonius C.G.M. Argentina Betrayed. Memory, mourning and accountability. Philadelphia: University of Pennsylvania Press, 2018. Jara, Daniela. Children and the Afterlife of State Violence. Memories of Dictatorship. New York: Palgrave Macmillan, 2016. Aranguren Romero, Juan Pablo. Managing Testimony and Administrating Victims. Colombia's Transitional Scenario under the Justice and Peace Act. New York: Palgrave Macmillan, 2017. 
Con frecuencia, en la discusión cotidiana, se habla acerca del valor de la memoria en los procesos de justicia transicional. Se repite en cada ocasión aquella frase, atribuida al filósofo de origen español George Santayana, que dice que los pueblos que no saben su historia están condenados a repetirla. También se afirma que la memoria es un componente esencial de los procesos de paz, pero sin explicar por qué y cómo la memoria del pasado contribuye a la paz. En principio estas frases parecen muy claras y que apuntan al corazón del problema. Sin embargo, es claro que los pueblos recuerdan su pasado y, pese a ello, lo repiten y, a veces, en más de una ocasión. No aparece relación alguna entre el olvido y la repetición del pasado 0 entre el recuerdo y su no repetición. ${ }^{6}$

En cuanto a la relación entre paz y memoria no se muestra cuál es el papel que juega en la construcción de la paz, sobre todo teniendo en cuenta lo que ya señalaba Todorov acerca de los abusos de la memoria como base para futuros conflictos? Se parte de la suposición de que recordar lo sucedido ayudará a las comunidades a superar el pasado traumático que han tenido vivir. ${ }^{8}$ Pero esto no pasa de ser uno de esos mantras que se repiten en el campo de la justicia transicional sin reflexión alguna.

Pero tal vez lo que más me llama la atención es que cuando se habla de memoria se confunde de manera intencional o no intencional las diferentes formas que adopta, como son la memoria individual, la colectiva, y la histórica. Y todo aquello que sirve para superar el trauma individual se extiende, sin mayor justificación, a las comunidades. ${ }^{9} \mathrm{Y}$ el término memoria histórica se convierte en un término que se aplica a todo, olvidando que las relaciones entre la memoria y la historia son complejas e involucran no solo el recuerdo de un pasado que no hemos vivido -0 sea la memoria histórica- y la calificación como historia de eventos del presente - 0 sea

6 Arthur, Palge. «How 'Transitions' Reshaped Human Rights: A Conceptual History of Transitional Justice.» Human Rights Quarterly 31, 2009: 321 - 367. RiefF, David. Elogio del Olvido. Barcelona: Debate, 2016.

En los estudios del Centro de Memoria Histórica de Colombia no se elabora una conceptualización de lo qué es la memoria o se problematiza su valor. En los textos se hace un trabajo de investigación sobre diversos acontecimientos que se consideran emblemáticos, pero sin aclarar cómo tales estudios son parte de un trabajo de construcción de memoria que se distinga de la labor de la historia. Ver a título de ejemplo (AAVV 2012) y (AAVV 2014).

7 Todorov, Tzvetan. Memoria del mal, tentación del bien: indagación sobre el siglo XX. Barcelona: Editorial Península, 2002.

8 Booth, James. Communities of Memory: on witness, identity and justice. Ithaca: Cornell, 2006.

9 Longman, Timothy. Memory and Justice in Post-Genocide Rwanda. Cambridge: Cambridge University Press, 2017. 
la historia del presente. ${ }^{10}$ Esto nos lleva entonces al difícil concepto de una memoria histórica del presente.

Hay dos instrumentos de la memoria que son con frecuencia utilizados: por una parte, están los documentos, normalmente contenidos en los archivos; y, por la otra, están los relatos de las víctimas. Los documentos suelen ser valorados como si contaran una verdad irrebatible, olvidando que han sido elaborados por los perpetradores y que en ellos pueden consignar falsedades para distorsionar el relato que se haga de sus acciones.11

El otro instrumento es el testimonio. De manera impropia se habla del testimonio de los sobrevivientes, esto es de las víctimas de las violaciones a los derechos humanos. Pero desde un punto de vista técnico, una persona solo puede ser testigo -esto es tercera- de un acto acontecido a otro. El relato del testigo es por tanto diferente del relato de la víctima y, por supuesto, del relato del victimario. ${ }^{12}$

En los estudios de la memoria y de la justicia transicional se suele dar relevancia al relato de las víctimas. Se suele asumir que lo dicho por las víctimas tiene un valor absoluto de verdad y no puede ser controvertido, pues de lo contrario estaríamos atentando contra su dignidad. Y, al lado de esto, se supone que todo lo sostenido por los perpetradores es falso, y por tanto no podemos creer absolutamente en lo que nos relatan. ${ }^{13}$

Sobre estos temas se ocupa Christopher Browning, quien analiza las declaraciones de Eichmann y las de algunas de sus víctimas. ${ }^{14}$ Browning encuentra

10 Aguilar Fernández, Paloma. Políticas de la memoria y memorias de la política. El caso español en perspectiva comparada. Madrid: Alianza Editorial, 2008.

11 Ginzburg, Carlo. El Queso y los Gusanos. El cosmos según un molinero del siglo XVI. Barcelona: Muchnik, 1982.

Por ejemplo, en los procesos contra los paramilitares en muchos casos los perpetradores niegan que haya habido violencia sexual simplemente porque los estatutos de la organización lo prohibían; o como cuando los Estados afirmar que no violan derechos humanos pues han ratificado diversos Convenios Internacionales de Derechos Humanos.

12 Sobre la importancia del estudio sobre el papel de los terceros ver el texto y la bibliografía de (Doná 2018). En el derecho penal, cuando una persona imputada declara en contra de un tercero, esto es, cuando se comporta como un tercero frente al acto de otro, se le toma juramento y se le escucha bajo la forma del testimonio. Cuando se trata de su propio acto declara libremente y no está ni siquiera obligado a decir la verdad. Es cierto que sí la víctima declara, lo hace bajo juramento. Es cierto también que se le trata como si fuera un testimonio. Pero mi análisis quiere ir más allá de lo meramente formalista y precisamente discutir su carácter de testimonio, esto es, de relato de un tercero frente a un acto realizado por otro. Sobre el tema ver: (Chiarloni 2018) (Páez Abril 2014).

13 Baer, Alejandro. Holocausto, Recuerdo y Representación. Madrid: Losada, 2006. Wiesel, Elie. Los Judíos del Silencio. Barcelona: Paidós, 1986.

14 Browning, Christopher. Collected Memories: Holocaust History and Postwar Testimony. Madison: University of Wisconsin Press, 2003. 
que el relato de Eichman es interesado y forma parte de su defensa judicial, pero de ello no se sigue que en todos los casos esté mintiendo. Por ello propone los siguientes criterios para valorar los relatos de los perpetradores: En primer lugar, la cuestión del mejor interés, esto es, si la declaración no beneficia a quien la da, ipor qué pensar que está mintiendo? En segundo lugar, cuando el relato está pleno de detalles muy vivos, es necesario analizarlo con seriedad, teniendo en cuenta la crítica a la participación del sujeto en esos eventos; y, en tercer lugar, analizar la posibilidad de ocurrencia del evento. Si el evento es probable, esto es, si coincide con lo dicho en otros documentos, esto hace mucho más probable su ocurrencia.

Si en este artículo Browning destaca la importancia del relato del perpetrador; en el segundo artículo de su libro se ocupa de analizar el relato del superviviente y aquí nos muestra algunas cosas muy interesantes. De entrada, aclara que el relato del superviviente puede ser auténtico, así no sea verdadero. Por ejemplo, muchos sobrevivientes han incorporado en su memoria las selecciones al llegar a Auschwitz e incluso algunos han afirmado que la selección la hizo Mengele. En muchos casos esto fue así, pero en otros los sobrevivientes incorporan un recuerdo ajeno, con mucha frecuencia popularizado en las películas. ¿Quiere esto decir que mienten? No. Sólo que su relato ha sido enriquecido con otras memorias, que no son propias sino de otros. Por tal razón, estos relatos, y estos testimonios deben ser siempre sometidos a crítica. Algo que solo se hace en el espacio del proceso penal, y que no se suele hacer en los espacios de construcción colectiva de la memoria histórica. ${ }^{15}$ El testimonio, cualquiera que sea, debe ser sometido a una severa crítica. Algo que se hace con mayor rigor en el espacio del proceso penal que en el de los estudios de la memoria 0, incluso, que en el de una Comisión de la Verdad.

En este texto, por tanto, quiero discutir la relación entre el testigo y el archivo y para ello me valgo del caso colombiano como un caso de estudio. Inicialmente

15 Esto lo ejemplifica con lo sucedido a Guta B. quien llegó a Birkenau el 30 de julio de 1944. En algunos relatos se afirmaba que Guta atacó a un guardia de las SS y que recibió un disparo. La dieron por muerta y ella busco refugio en una de las barracas. Al otro día, al no encontrar su cuerpo, los guardias hicieron una búsqueda y al no encontrarla amenazaron a todos los judíos del campo. Ella decidió entregarse y frente a su valentía un comandante de las SS le perdonó la vida. Sobre este mismo hecho existen diferentes versiones, incluso de la propia sobreviviente, que declaró sobre ello en 1968. Pero tal vez el hecho más interesante es el de la muerte de la elite gobernante judía de uno de los campos en uno de los trenes de transporte. Al principio los testigos declararon que habían muerto por razones del transporte. Pero luego se supo, en las investigaciones del propio Browning, que habían sido asesinados por sus propios compañeros, como castigo por los privilegios que tenían en el campo. Browning concluye afirmando que el relato de los supervivientes y sus testimonios no pueden tener un privilegio acordado solo por su procedencia (Browning 2003). Para una defensa del proceso penal como un mecanismo de justicia transicional, ver (Vera Sánchez 2016 - 2017). 
analizo la cuestión de la memoria y posteriormente me ocupo de analizar las relaciones entre verdad y memoria. Con este texto, pretendo hacer un aporte a los estudios de justicia transicional que dan por sentada, sin más, la validez de los aportes documentales o de los relatos de las víctimas y de los testigos. ${ }^{16}$ No se trata de una mera pretensión teórica, pues de ello depende la elaboración de criterios de verdad tanto para el juicio penal como para las Comisiones de la Verdad.

\section{La memoria como un deber}

De acuerdo con Leebaw ${ }^{17}$, uno de los objetivos tradicionales de la justicia transicional es el establecimiento de un registro histórico de la violencia política, todo ello con el fin de combatir la negación de la existencia de una violencia sistemática. Para el filósofo alemán Jürgen Habermas, confrontar y recordar el pasado contribuye a reforzar el compromiso con los valores y con las reformas democráticas. ${ }^{18}$ Sin embargo, en otros casos los hallazgos de los diferentes mecanismos de justicia transicional han sido ignorados, rechazados o no han sido puestos en conocimiento del público. Para Adorno, en la misma tradición de la Escuela de Frankfurt, el proceso alemán de enfrentarse al pasado funcionaba como una forma de protegerse en contra de las implicaciones morales del recuerdo tratando a las memorias dolorosas como parte de un complejo de culpa. Para Adorno hablar del pasado no necesariamente contribuye a luchar contra la impunidad y más bien puede servir a un propósito opuesto. ${ }^{19}$ Por ello, conviene no tomar la memoria de una manera simplista, sino tener en cuenta las posibilidades de hacer frente al pasado, pero también los riesgos de su presencia. ${ }^{20}$

16 Las referencias son amplias. Pero basta con mostrar dos textos recientes: en uno, la autora analiza la cuestión de la memoria y de los memoriales a partir de documentos oficiales y no oficiales, pero sin someter a una crítica racional a las fuentes documentales de las que se vale (Fabri 2013). En otro, más reciente, se analiza la ley de memoria histórica de España. Se somete a crítica el concepto de memoria, se sugiere la inclusión de una perspectiva feminista, pero no se hace lo propio con los documentos o con la idea misma del archivo. Como si los archivos no tuvieran a su vez sesgos de género, raza o ideología (Rosón y Lucas Platero 2017).

17 LeeBaw, Bronwyn AnNe. "The Irreconcilable Goals of Transitional Justice.» Human Rights Quarterly vol. 30 No. 1, February 2008: 95 - 118.

18 Habermas, Jünger. Facticidad y Validez. Barcelona: Trotta, 1998.

19 Adorno, Theodor. "La educación después de Auschwitz.» En Crítica cultural y sociedad, de Teodoro Adorno. Madrid: Sarpe, 1984.

20 RiefF, Davio. Elogio del Olvido. Barcelona: Debate, 2016.

En el caso camboyano, por ejemplo, se ha resaltado el papel que juega el olvido y los peligros de la memoria. Para los camboyanos, no se debe poner un palo en una herida que está cerrando. Por ello 
En la discusión sobre la justicia transicional, encontramos una concentración sobre el papel de la justicia, de la verdad y de la reparación. En esta triada se han basado las diferentes políticas dentro del campo. Sin embargo, se olvida en la teoría, que no en la práctica, un aspecto fundamental como es el de la memoria. Con frecuencia se habla de la memoria individual, colectiva e histórica. Incluso se desarrolla una disputa alrededor de este concepto de memoria histórica como si fuera uno contradictorio. ${ }^{21}$ Más bien se trata, como lo explica Aguilar, de un concepto que apunta al recuerdo del individuo -memoria individual-; al recuerdo construido y compartido por el grupo -memoria colectiva-; y al recuerdo que quiere ser historia, memoria histórica. ${ }^{22}$

Una vez la memoria ha entrado en el campo de la justicia transicional se puede incurrir en un abuso de esta, pues no siempre se recuerda en el sentido de contribuir a las causas de las víctimas, en muchas ocasiones el recuerdo apunta a señalar una herida 0 un agravio que debe ser subsanado 0 un agravio que deber ser castigado, como lo muestra el caso del conflicto en la Antigua Yugoslavia. ${ }^{23}$ Al mismo tiempo se da una lucha contra el olvido y por el olvido. Detrás de muchos de los gestos de memoria abunda el olvido, pues la memoria se convierte en el mecanismo de selección de aquello que debemos olvidar. Como lo señala Hector Schmucler en el prólogo al libro de Claudia Feld,

la imposibilidad humana de vivir sin olvidar no debería entenderse como un elogio de la amnesia, sino como condición para que la memoria persista seleccionando lo que no debe ser abandonado. La forma más engañosa del olvido es la pretensión de que todo está presente en el mismo tiempo. La memoria humana no prescinde de la capacidad de elegir. ${ }^{24}$

En algunos casos como el argentino y el colombiano, el olvido es mucho más explícito y se desarrollan estrategias de olvido del pasado, de manera que se dejan de lados las responsabilidades y el acontecimiento se presenta como un hecho

la Cámara Especial creada para juzgar a los perpetradores del Khmer Rouge ha sido recibida con poco entusiasmo por la ciudadanía (Hinton 2016) (Hinton 2018).

21 Bergall, Roberto. Memoria colectiva como deber social. Barcelona: Anthropos, 2010.

22 Agullar Fernández, Paloma. Políticas de la memoria y memorias de la política. El caso español en perspectiva comparada. Madrid: Alianza Editorial, 2008.

23 Todorov, Tzvetan. Memoria del mal, tentación del bien: indagación sobre el siglo XX. Barcelona: Editorial Península, 2002.

24 Feld, Claudia. Del estrado a la pantalla: las imagines del juicio a los excomandantes en Argentina. Madrid: Siglo XXI, 2002. 
neutro. Por ello la memoria apela al recuerdo de aquello que fue olvidado, pues del recuerdo depende también la identidad del grupo 0, como lo señala Booth ${ }^{25}$, se dan comunidades de memoria, pues el relato es uno del grupo y en la medida en que cuenta 0 en que da cuenta constituye al grupo. El olvido reconstituye al grupo, hace que se convierta en otro grupo diferente al que recuerda. Lo que demuestra que la memoria requiere de gestos para su preservación, y estos no son inocentes, sino que forman parte de la lucha política que se da en el campo de las memorias. Pero esto al mismo tiempo nos indica que el gesto pudo haber sido otro, que la memoria es contingente, que el recuerdo y el olvido son dependientes de las luchas de las memorias y que lo que hoy recordamos y cómo lo recordamos es el resultado de esas luchas y, por tanto, el resultado de unas luchas por el poder. Esas luchas se dan en lo que Claudia Feld ha denominado "escenarios de la memoria", esto es, "el espacio en el que se hace ver y oír a un público determinado un relato verosímil sobre el pasado". ${ }^{26}$ Esto supone tener en cuenta la dimensión narrativa, quién cuenta, cómo y para quién; una dimensión espectacular, la puesta en escena, en donde importan los lenguajes y los elementos usados en la escenificación; y la dimensión veritativa, en donde se analiza la producción de la verdad y en donde importa el tipo de verdad sobre el pasado que se construye y la lucha que se da con otras verdades. Por ello el espacio de producción de la verdad es distinto en el juicio penal y en las Comisiones de la Verdad.

No quiero detenerme en las razones por las cuales los Estados están obligados a garantizar que no haya impunidad, sino que quiero destacar el papel que cumple la justicia para determinar lo memorable, esto es, lo que es merecedor de memoria. La memoria es en sí misma justicia, como lo señala el filósofo español Manuel Reyes Mate, pero también depende de la justicia. ${ }^{27}$

Si entendemos que la injusticia es lo primero y que la justicia responde primero a una injusticia, entonces debemos afirmar que la memoria también responde a un reclamo de justicia. Pero ¿cómo saber cuál es ese reclamo? Se podría decir que basta con escuchar a las víctimas y con establecer mecanismos de participación en la producción de la memoria. Sin embargo, la mera participación no parece ser suficiente, pues ello nos dejaría solamente en el campo del conocimiento y las víctimas también quieren reconocimiento. Ahora, ese reconocimiento supone

25 Воотн, James. Communities of Memory: on witness, identity and justice. Ithaca: Cornell, 2006.

26 Feld, Claudia. Del estrado a la pantalla: las imagines del juicio a los excomandantes en Argentina. Madrid: Siglo XXI, 2002

27 Mate, Manuel Reyes. Tratado de la Injusticia. Barcelona: Anthropos, 2011. 
que los perpetradores reconozcan, retornen al lugar simbólico de la vulneración y asuman que ello no debió ser. ${ }^{28}$ Pero si no queremos un reconocimiento cínico, ese reconocimiento debe estar acompañado de justicia. ${ }^{29}$ No basta con reconocer que son culpables e inmediatamente admitir la posibilidad de no cumplir la pena impuesta, que para delitos graves es privativa de la libertad.

Jean Amery ha trabajado este tema de una manera muy profunda. Al analizar la cuestión del resentimiento, Amery muestra cómo las víctimas continúan aferradas a ese momento pasado. No es suficiente que el perpetrador afirme que lo siente, también debe haber una suerte de justicia, púes solo en ese momento el tiempo pasado se anula, pues tanto víctima como victimario desean que lo sucedido no haya pasado. ${ }^{30}$ En esa medida, la memoria sirve para que haya justicia, pero ella sola no es justicia. Al mismo tiempo, la justicia señala lo memorable, destaca que el tiempo pasado no debió ser y se abre hacia el futuro, hacia la no repetición.

La memoria se concibe como un espacio de lucha política, y esta lucha con frecuencia se entiende como lucha contra el olvido, esto es, como un recordar para no repetir. Con frecuencia se hace la distinción entre la memoria colectiva, la memoria individual y la memoria histórica. Como lo ha destacado Ricoeur, "la memoria colectiva solo consiste en el conjunto de huellas dejadas por los acontecimientos que han afectado al curso de la historia de los grupos implicados que tienen la capacidad de poner en escena esos recuerdos comunes con motivo de fiestas, los ritos y las celebraciones públicas. ${ }^{31}$ Por ello es importante destacar el proceso de construcción de las memorias y dejar abierta la investigación a la existencia de memorias dominantes, hegemónicas, únicas u oficiales ${ }^{32}$ como las que se encuentran en los archivos oficiales 0 en las sentencias judiciales.

Las luchas por la memoria se dan entre diversos actores que reclaman el reconocimiento y la legitimidad de su palabra y de sus demandas. Por ello la memoria de los grupos marginados surge con una doble pretensión: la de decir la verdad de

28 Amery, Jean. Más allá de la culpa y de la expiación: tentativas de superación de una víctima de la violencia. Valencia: Pre-Textos, 2004.

29 Payne, Lelgh. Unsettling Accounts: Neither Truth Nor Reconciliation in Confessions of State Violence. Durham: Duke University Press, 2007.

30 Amery, Jean. Más allá de la culpa y de la expiación: tentativas de superación de una víctima de la violencia. Valencia: Pre-Textos, 2004.

31 Ricoeur, Paul. La lectura del tiempo pasado: memoria y olvido. Madrid: Universidad Autónoma de Madrid, 1999.

32 Jelin, Elzabeth. Los trabajos de la memoria. Buenos Aíres: Siglo XXI, 2002. 
su victimización y la de reclamar justicia. ${ }^{33}$ Pero la memoria requiere de la historia para no caer en una presentación unilateral o distorsionada del sufrimiento de las víctimas, por ello la memoria no puede ser simplemente universal o colectiva, debe también ser histórica. ${ }^{34}$

En la siguiente sección me ocupo de analizar la verdad judicial en los procesos de justicia transicional, pues se trata de un campo poco estudiado cuando se habla de la justicia transicional y de las garantías de no repetición. Se asume, sin justificación alguna que el proceso judicial da verdad o, sin mayor evidencia, que la única verdad posible es la verdad de los historiadores o la de la Comisión de la Verdad. ${ }^{35}$

\section{La verdad en el Proceso Judicial}

En la discusión sobre los fines del proceso penal se afirma que éste tiene como pretensión alcanzar una verdad procesal, con sus propios criterios de validez y con sus propias formas de alcanzarla. Esta verdad difiere de la de las ciencias sociales y de las ciencias físicas, pues en ellas un método determinado conduce a alcanzar la verdad sobre el mundo ${ }^{36}$. En este apartado no me interesa discutir sobre la verdad en un sentido amplio, ni hacerme cargo de todas las teorías de la verdad. Me interesa concentrarme en la determinación de qué es la verdad judicial y cuál es su relación/ diferencia con la verdad histórica. Esta es una discusión importante, pues en los procesos de justicia transicional la verdad adquiere un papel central y por tanto es relevante determinar de dónde proviene la verdad sobre el pasado y cómo se le identifica.

Para Nicolás y Frápolli37, la verdad es uno de los temas centrales en la filosofía y ello se debe a cuatro razones fundamentales:

33 Ibíd. Mate, Manuel Reyes. Tratado de la Injusticia. Barcelona: Anthropos, 2011.

34 En el caso colombiano se ve que se adoptó un modelo de justicia transicional en el que inicialmente ponía toda la carga de la búsqueda de la verdad y de la justicia en la justicia penal. Al mismo tiempo, dejaba en sus manos la determinación de la reparación que los desmovilizados debían hacer a sus víctimas. En un primer momento, y dado el marco de derecho penal internacional existente, Colombia hizo una apuesta fuerte por la justicia, o por lo menos eso parecía.

35 Aller Montaño, Eugenia; Crenzel, Emilio (eds). Las luchas por la memoria en América Latina. Historia reciente y violencia política. Madrid: Iberoamericana, 2016. Ortega-Ruíz, Luis German, y Juan Pablo García Miranda. «La verdad en la justicia transicional.» lusta No. 50 (Enero - Junio ), 2019: 39 - 63.

36 WeIGend, Thomas. «ls the criminal process about truth? A German perspective.» 26 Harvard Journal of Law and Public Policy , 2003.

37 Nicolas, Juan Antonio, y María José (eds) Frapolu. Teorías Contemporáneas de la Verdad. Madrid: Tecnós, 2012. 
116 El archivo y el testigo. Un análisis de la relación entre memoria y justicia a partir del caso colombiano -

Farid Samir Benavides Vanegas

a. Toda reflexión deber partir del factum del conocimiento y en particular del factum de la verdad.

b. Toda acción cognoscitiva racional debe contar como uno de sus fines la obtención de resultados verdaderos.

c. Las adscripciones de verdad en los lenguajes naturales son medios poderosos de generalización proposicional.

d. Aquello que se entiende como verdadero forma parte del conjunto de acción social e individual que constituye la vida humana.

Una teoría de la verdad debe dar cuenta de varios elementos como el concepto de verdad, los criterios para determinar cuándo un enunciado es verdadero o falso, las dimensiones de la verdad y la distinción entre los diferentes tipos de verdad. Para lo que nos interesa en este trabajo es importante determinar cómo se define la verdad que se produce en el proceso judicial y cómo se hace en el campo de la historia. Pero igualmente es necesario determinar si la memoria se ocupa del recuerdo de una verdad o simplemente del recuerdo del pasado tal y como lo recuerda la persona desde su propio punto de vista particular, con independencia de si es verdadero o falso. Igualmente, es importante destacar el lugar de la verdad y la memoria dentro de un proceso de justicia transicional como el colombiano. Si afirmamos que la verdad que cuenta es la del proceso judicial, esto tiene implicaciones para el papel de la víctima y para la narrativa final del conflicto. Pero lo propio es cierto si afirmamos que lo que cuenta es la verdad de los historiadores, pues ello supondría negar validez al relato construido dentro del proceso penal.

En las discusiones sobre el papel de la verdad nos movemos entre dos posiciones muy marcadas: por una parte, aquellos que sostienen que el proceso -judicial y no judicial- debe apuntar a dar la verdad de lo que sucedió asumen que es posible encontrar una verdad de los hechos, lo que los ubica dentro de la visión de una teoría de la correspondencia. ${ }^{38}$ Para estos autores la verdad se entiende en un sentido aristotélico, esto es se entiende que "la verdad es una propiedad de los juicios, y no de las cosas o de los conceptos, o de las representaciones 0 de las vivencias. Concretamente la verdad es una propiedad exclusiva de los enunciados que describen la realidad. Un juicio es verdadero si se corresponde con, o si es adecuado a, la realidad objetiva. Esta correspondencia se interpreta como reflejo: el

38 Sanabria Torres, Luisa Paola. «Investigación social para la paz en Colombia: entre la verdad histórica y la prueba judicial.» En El proceso de paz en Colombia. Disertaciones alrededor de una historia, de Dory Luz Gonzalez Hernández. Bogotá: Los Libertadores, 2016. Rodríguez Serpa, Ferney Asdrùbal, Nelhiño Bolaño Miranda, y Gloria María Algarín Herrera. «De la valoraciòn racional de la prueba en la verdad procesal a la teoría de la probabilidad preponderante.» Jurídicas CUC vol. 14 No. 1, 2018: 259 - 286. 
conocimiento es el reflejo subjetivo de la realidad objetiva en la conciencia. Si ese reflejo es correcto (no distorsionado), entonces estamos en la verdad". ${ }^{99}$

Por la otra, están quienes sostienen que el proceso de justicia transicional con todos sus mecanismos apunta a la construcción de una verdad consensuada, esto es, que todos los puntos de vista sean tenidos en cuenta en el relato del pasado. Esta visión se basa en una teoría pragmática de la verdad, en particular en la teoría de Habermas. ${ }^{40}$ Una teoría pragmática de la verdad se caracteriza por el reconocimiento que todo conocimiento está lingüísticamente mediado. Por ello, para Habermas, la racionalidad está configurada por la teoría de las pretensiones de validez de la comunidad lingüística.

Se trata de cuatro pretensiones contenidas en todo juego lingüístico que funcione; por ello constituyen un consenso de fondo, que solo se hace manifiesto cuando alguna de esas pretensiones presupuestas se pone en cuestión. Las cuatro pretensiones de validez son: inteligibilidad (condición de la comunicación misma), verdad y rectitud (pretensiones resolubles en el discurso) y veracidad (solo resoluble en la acción). La teoría consensual de la verdad comprende no solo la verdad de los enunciados, sino también la rectitud de las normas y las valoraciones. ${ }^{41}$

Como la verdad no se plantea en el contexto de la praxis, sino en el discurso, lo que importa es la forma argumentativa de comunicación y por ello la cuestión de la verdad es una de justificación en el discurso. En esta teoría se liga verdad y validez y con ello se destaca el carácter intersubjetivo del discurso. Y aquí debe hacerse énfasis en la idea de un consenso ideal como una idea reguladora. El consenso ideal es definido como "el que se produciría en torno a un enunciado al que cualquier interlocutor racional que pudiera participar en su discusión asentiría, siempre que se dieran unas ciertas condiciones que constituyen lo que sería la situación ideal del habla" ${ }^{42}$ Así toda acción comunicativa no distorsionada se mueve por el impulso de

39 Nicolas, Juan Antonio, y María José (eds) Frapolu. Teorías Contemporáneas de la Verdad. Madrid: Tecnós, 2012

40 Galán Vélez, Francisco Vicente. «Verdad Pragmática y Verdad Consensual en Habermas; una lectura lonargeneana.» Universitas Philosophica Vol. 31 No. 62 (enero-junio), 2014 : 113 - 145. HAACK, Susan. "Truth, Truths, "Truth", and "Truths" in the Law.» 26 Harvard Journal of Law and Public Policy, 2003: $17-21$.

41 Nicolas, Juan Antonio, y María José (eds) Frapolli. Teorías Contemporáneas de la Verdad. Madrid: Tecnós, 2012

42 Ibíd. 
la búsqueda cooperativa de la verdad, y es este horizonte el que configura la noción de consenso.

Para Habermas, una situación ideal del habla es aquella que no está distorsionada por coacciones. Esto solo se da si hay una distribución simétrica de las oportunidades de elegir y ejecutar actos de habla. Para ello se deben dar las siguientes condiciones:

a. Todos los participantes potenciales en un discurso tienen que tener la misma oportunidad de emplear actos de habla comunicativos, esto es, todos deben tener la oportunidad de abrir un discurso y de perpetuarlo mediante sus intervenciones.

b. Todos los participantes en el discurso deben tener la oportunidad de hacer interpretaciones, afirmaciones, recomendaciones, dar explicaciones y justificaciones y de problematizar, razonar o refutar las pretensiones de validez de ellas, de manera que todos los prejuicios puedan ser sometidos a críticas.

c. Para los discursos solo se permiten hablantes que como agentes del discurso estén en condiciones de igualdad para expresar actos de habla representativos, es decir, que manifiesten actitudes, sentimientos y deseos. Que los participantes en el discurso sean transparentes y veraces unos con otros.

d. Para el discurso solo se permiten hablantes que como agentes tengan la misma oportunidad de emplear actos de habla regulativos, esto es, de mandar y oponerse, de permitir y prohibir. ${ }^{43}$

Esto no significa que se trate de una verdad de las mayorías, sino del sometimiento de la producción de la verdad a condiciones estrictas, de manera que podamos establecer con referencia a un modelo ideal cuándo un discurso no es verdadero, es decir, cuando se aleja de esas condiciones. Esto hace que no podamos hablar de La Verdad, sino de una verdad siempre falible. Se trata del consenso como un lugar de la verdad, pero no se trata de un lugar epistémico, sino de un lugar moral, en donde el consenso opera como idea regulativa, admitiendo solo la fuerza del mejor argumento. Como lo señala Pérez Tapias,

la imperativa búsqueda del consenso exige el reconocimiento de todos los demás como interlocutores válidos, en lo que a competencia comunicativa se refiere, respetándolos además en la dignidad que implica su derecho a tomar la palabra y ofrecer sus argumentos. El consenso como lugar de la 
verdad se apoya en exigencias incondicionales de reconocimiento de la alteridad. ${ }^{44}$

Las Comisiones de la Verdad parecen ser el lugar más adecuado para un modelo pragmático de la verdad, pues en ellas los diferentes actores hacen su relato del pasado en condiciones cercanas a las condiciones ideales del discurso, y corresponde a la Comisión construir el relato del pasado que sea el resultado de todos los relatos expuestos. En el proceso penal, por el contrario, la verdad se construye de otra manera y siempre de manera autoritativa, esto es, corresponde al juez establecer qué es la verdad y ello lo hace en la sentencia luego de agotar todos los pasos establecidos en la ley. Sin embargo, la idea de la igualdad de armas en el proceso penal no permite pensar en una situación ideal en la que todos los hablantes tengan las mismas oportunidades de emitir enunciados con pretensiones de verdad y de aportar las pruebas necesarias para ello.

Si entendemos que la decisión judicial se basa en una inferencia lógica que se hace a partir de las premisas normativas y fácticas (la selección de los hechos viene dada por las normas, pues desde estas se determinan cuáles son los hechos que son relevantes para la decisión judicial), podemos afirmar que las elecciones del juez son el resultado de un proceso de recorte o de acotamiento de la realidad basados en el criterio de relevancia determinado por las normas. ${ }^{45}$ Como se tratan de enunciados sobre los hechos, la cuestión fundamental del proceso es cómo alcanzar la verdad de los hechos, es decir, cómo formular enunciados verdaderos con respecto a una situación fáctica. Vera Sánchez muestra la importancia del proceso penal como lugar de producción de verdad al destacar los medios del Estado que se ponen a disposición del proceso para la búsqueda de la verdad. ${ }^{46}$

Para Michele Taruffo el proceso se funda en una concepción de la verdad como correspondencia, pero agrega que la verdad es relativa, pues los medios de conocimiento son limitados, se hallan regulados por el propio proceso legal y el contexto hace que la formulación de enunciados sea dependiente de presuposiciones, conceptos y reglas de ese ámbito. La prueba legal se sujeta a una serie de reglas

44 Pérez Tapias, José Antonio. "Verdad de la Justicia y Poder de la Mentira." En El valor de la verdad. Hermenéutica, semántica, política, de Juan Antonio Nicolás y María José (eds) Frapolli, 479 - 538. Granada: Comares, 2000.

45 Ferrer, Jordi, y Daniel Mendonca. "Introducción.» En Verifobia. Un diálogo sobre prueba y verdad, de Michele Taruffo. Lima: Palestra Editores, 2012.

46 Vera Sánchez, Juan Sebastián. "Cuatro mitos sobre la justicia retributiva como mecanismo de justicia transicional.» 32 American University International Law Review 469, 2016 - 2017: 469 - 499. 
como la admisibilidad de los medios de prueba, la formación de la prueba dentro del proceso, la valoración de la prueba producida y la exposición en el fallo de los juicios acerca de los hechos probados dentro del proceso. ${ }^{47}$

Taruffo muestra cómo existe una suerte de consenso con respecto al valor de las pruebas para alcanzar una verdad procesal, que puede ser diferente a la verdad histórica. Igualmente destaca la visión tradicional de ver al proceso para resolver las controversias entre las partes, pero no para alcanzar la verdad de los hechos. Con ello se da una contradicción entre la teoría de la prueba - que afirma que están para la determinación de la verdad- y la teoría del proceso -que afirma que su función es producir una verdad formal para resolver el caso concreto. Taruffo rechaza las concepciones consensualistas de la verdad pues considera que no se explicitan los criterios de producción de la verdad y agrega que

se puede definir racionalmente el consenso que se manifiesta en muchos sistemas sobre criterios de conocimiento de los hechos que se funden sobre la máxima correspondencia posible entre lo que afirma el juez y lo que ha sucedido verdaderamente en el mundo real. ${ }^{48}$

En todo caso, la verdad que se debe producir no es una verdad absoluta, pues el proceso no es una actividad científica ni filosófica y basta con una verdad relativa que pueda ofrecer bases razonables para la decisión. ${ }^{49}$ En tanto que es una verdad relativa se limita a ofrecer la mayor aproximación a la determinación de los hechos con la realidad, el proceso entonces no sólo busca producir la verdad, sino que no se trata de una verdad simplemente formal. Taruffo elude la discusión entre verdad histórica y verdad procesal, pues considera que cada una se ocupa de buscar la verdad, con lo que le quita primacía a la verdad histórica. Taruffo afirma lo siguiente:

En cualquier caso, mi opinión es que el proceso no sólo pretende producir decisiones, sino también decisiones justas. Como ya he dicho anteriormente, pienso que una decisión sólo puede ser justa si se funda en una determinación verdadera de los hechos del caso (además de derivar

47 Ferrer, Jord, y Daniel Mendonca. «Introducción.» En Verifobia. Un diálogo sobre prueba y verdad, de Michele Taruffo. Lima: Palestra Editores, 2012.

48 Taruffo, Michele. La prueba de los hechos. Madrid: Trotta, 2002.

49 Ibíd.

Susan Haack analiza la diferencia entre la verdad del proceso y la verdad de la ciencia. Ella concluye su análisis señalando que las verdades legales son verdaderas por virtud de las decisiones judiciales; las verdades científicas son verdaderas por virtud del carácter de los fenómenos y de los eventos en el mundo -esto es por su correspondencia con la realidad; y no por argumentos legales o como resultado de un proceso judicial (Haack 2008). 
de un proceso correcto y de la justa interpretación y aplicación de las normas). Por tanto, el verdadero problema no es si debe o no buscar la verdad de los hechos en el proceso y tampoco si la verdad puede o no ser alcanzada en abstracto, sino comprender cuál es la verdad de los hechos que puede y debe ser establecida por el juez para que constituya el fundamento de la decisión ... En términos más analíticos se puede decir que se ha establecido la verdad de un hecho cuando el enunciado que lo describe ha obtenido, sobre la base de los conocimientos aportados por las pruebas y por las inferencias basadas en estas, un grado de confirmación lógica prevaleciente sobre el que puede ser atribuido a cualquier hipótesis, de modo que resulta racional escoger ese enunciado como descripción verdadera del hecho en cuestión. En resumen, la verdad del enunciado es una función de la confirmación lógica que puede derivarse de las pruebas que a él se refieren. ${ }^{50}$

En la producción de la verdad dentro del proceso judicial se reconocen dos limitaciones: las reglas procesales que determinan las formas en las que se pueden demostrar los hechos y la institución de la cosa juzgada, que obliga a establecer límites a las posibilidades de discutir sobre los hechos ${ }^{51}$. Por su parte, González Lagier muestra los problemas de percepción y de interpretación que se dan cuando se trata de conocer los hechos. Este autor muestra que podemos tener problemas derivados de las limitaciones de nuestros órganos sensoriales, la posibilidad de ilusiones, la posibilidad de alucinaciones, y la mediación de nuestra subjetividad a través de la interpretación. ${ }^{52}$ Este es un problema de la verdad en el proceso judicial, pero se incrementan cuando se tratan de procesos transicionales en los cuales se quiere establecer un relato autoritativo y consensual sobre el pasado, de manera que todas las partes puedan dar su asentimiento a ese relato. La pregunta que surge es: ¿Es el proceso penal el indicado para alcanzar esa meta?

El proceso penal es el espacio en el cual se define la responsabilidad de una persona y, por consiguiente, la aplicación de una pena determinada o de una medida de seguridad. De tal manera, el proceso penal es un espacio de confrontación de dos actores con el fin de dar cuenta de la verdad de los hechos objeto de juzgamiento. ${ }^{53}$

50 Ibíd.

51 Ferrer Beltrán, Jordi. Prueba y Verdad en el Derecho. Barcelona: Marcial Pons, 2002.

52 González Lagier, Daniel. Questio Facti. Ensayo sobre prueba, causalidad y acción. Bogotá: Temis, 2005.

53 Malem, Jorge. El error judicial y La formaciòn de los jueces. Madrid: Fundación Coloquio Jurídico Europeo, 2009. 
La decisión sería injusta si no se basa en los hechos. Se fundamenta en el deber que tiene el juez de aplicar el derecho, "ya que ese deber quedaría incumplido si el juez impone consecuencias normativas a hechos diferentes a los establecidos por el legislador". ${ }^{54}$

Como lo señala Thomas Weigend, el proceso penal se ocupa de la verdad, por lo mismo, resulta relevante la forma en la que se determinan los hechos. ${ }^{55}$ Si bien el proceso penal tiene una serie de objetivos señalados, como la búsqueda de un acuerdo entre las partes, la determinación de la pena, etc., lo cierto es que ninguna de estas medidas puede tener lugar si antes no se ha logrado establecer qué pasó realmente, esto es, cuáles son los hechos que permiten deducir las consecuencias previstas en la ley.

En los procesos de justicia transicional, la búsqueda de la verdad es uno de los pilares centrales sobre los que se basan los mecanismos no punitivos de transición. "Con el fin de lograr el cierre de eventos traumáticos, parece más importante determinar y hacer público qué sucedió realmente que imponer sanciones penales". ${ }^{56}$ Por ello, en este tipo de procesos transicionales se busca que la verdad surja como parte de la no repetición de los hechos, pues en la medida en que conozcamos qué sucedió podremos decir realmente cuáles son las medidas a tomar para evitar su repetición.

Sin embargo, no todos los actores dentro del proceso penal están obligados a la búsqueda de la verdad y, sobre todo, en el proceso penal existen límites para su búsqueda. Es decir, no es posible afirmar que dentro del proceso se deba alcanzar la verdad a cualquier costo. El derecho del procesado a guardar silencio, e incluso el derecho a mentir y a presentar su propia versión de los hechos, nos muestra los límites que tenemos dentro del proceso penal. En los modelos procedimentales, tanto anglosajón como continental, la anulación de la verdad conseguida con violación de ciertas reglas de procedimiento conduce a afirmar que la verdad no se puede obtener sin más y que resulta necesario que sea alcanzada mediante una actuación válida frente a la Constitución y las leyes.

54 lbíd.

55 WeIgend, Thomas. "Is the criminal process about truth? A German perspective.» 26 Harvard Journal of Law and Public Policy , 2003.

56 WeIgend, Thomas. «Should we search for the truth? and, who should do it?» N.C.J. International Law \& Com. Reg. XXXVI, 2010. HaAck, Susan. Evidence Matters. Science, Proof, and Truth in the Law. Cambridge: Cambridge University Press, 2014. 
Los diferentes sistemas procesales hacen énfasis en la necesidad de la búsqueda de la verdad dentro del proceso, pero no definen la naturaleza de esa verdad. Pero puede afirmarse que la noción que se maneja en el proceso penal es también la de la verdad como correspondencia, esto es, la identidad entre el sujeto y el objeto en cuanto a la afirmación de lo que es verdadero. De este modo, si X mató a $Y$, el enunciado es verdadero si efectivamente $X$ realizó la acción de matar a $Y$. Pero la determinación de la verdad también tiene importancia para alcanzar el efecto preventivo de la pena, pues si se impone una pena a $X$ sin haber efectivamente realizado la conducta, la decisión se verá como injusta y, en todo caso, no alcanzará al verdadero culpable..$^{57}$

Una aproximación diferente es reconocer el carácter construido de la verdad, como en las Comisiones de la Verdad. Sin embargo, el proceso penal se caracteriza por el enfrentamiento entre los sujetos y, por tanto, por la ausencia de cooperación para la producción de la verdad. En el proceso penal los actores buscan presentar su propia versión de los hechos, conforme a ciertas reglas que les obligan a revelar aquello que han averiguado, pero que no les obligan a buscar lo que puede perjudicar a sus clientes - si se trata de la defensa - 0 que pueda beneficiar el caso del procesado — si se trata de la acusación—. Si se acoge la idea de que la verdad es una suerte de oro que se debe encontrar, entonces lo que la legitima es el resultado y no el procedimiento. Si se trata de una visión constructivista, lo que legitima la verdad producida es el procedimiento y no simplemente el resultado. ${ }^{58}$

Andrés Páez analiza las relaciones entre el testimonio y la epistemología y las disputas entre los reduccionistas y los anti-reduccionistas con respecto al valor del testimonio para servir como prueba de los hechos. La primera posición se asocia con David Hume, para quien el valor de los testimonios se deriva de nuestra experiencia del pasado en la que los testigos han demostrado ser veraces. En la versión contemporánea de la teoría se muestra que se requieren dos condiciones para justificar nuestras creencias testimoniales: una, el oyente debe tener razones positivas para aceptar el testimonio de un testigo; $y$, dos, las razones no pueden ser testimoniales, pues se caería en un círculo vicioso, es decir el testimonio debe ser reducido a las otras fuentes de justificación epistemológica, como la evidencia sensorial, la información proveniente de la memoria y del razonamiento inductivo.

57 Malem, Jorge. El error judicial y La formaciòn de los jueces. Madrid: Fundación Coloquio Jurídico Europeo, 2009.

58 Taruffo, Michele. La prueba de los hechos. Madrid: Trotta, 2002. 
El anti-reduccionismo surge de la forma en la que analizamos la información testimonial en la vida cotidiana, pues nuestras creencias surgen de los demás sin que las sometamos a crítica alguna. Nuestra tendencia es a aceptar el testimonio de los demás, a menos que tengamos buenas razones para no hacerlo. ${ }^{59}$

Uno de los aspectos más importantes es cómo juzgar el valor probatorio del testimonio. ${ }^{60}$ En la tesis reduccionista debemos aportar razones para creerlo, por mínimas que sean; en la anti-reduccionista es todo lo contrario, debemos aportar razones para no creerlo, a pesar de lo ingenuo que pueda parecer. En el derecho penal colombiano se acepta una tesis reduccionista, pues el testigo merece credibilidad luego de una mínima prueba de control sobre su veracidad. ${ }^{61}$

En el caso de la valoración de los testimonios se acude a una tesis anti - reduccionista, pues muchos de los elementos probatorios para acreditar 0 desacreditar al testigo constituyen información que ninguna de las partes en el proceso ha verificado personalmente, pues en muchos casos se acude al testimonio de expertos para verificar un testimonio directo, como cuando pedimos un peritaje para demostrar que el testigo tenía la visibilidad necesaria para ver lo que ha dicho que vio. Como señala Páez, "el análisis de la credibilidad de la prueba testimonial demuestra que el espíritu de las normas es reduccionista en el sentido de exigir la presentación de razones positivas para justificar el testimonio, pero que es imposible pretender que en todos los casos dichas razones puedan ser reducidas a fuentes más básicas y confiables". ${ }^{62}$ En el análisis del testimonio desagregamos aquello que es relevante por su valor probatorio y aquello que no. Y con frecuencia esta parte irrelevante no es sometida a crítica, pues incluso siendo falsa no afecta el carácter veritativo del relato. Así, si un testigo miente sobre el nombre de su Edificio y está dando testimonio sobre un hecho ajeno a ese nombre, pues el testimonio no pierde ninguna validez. Esto es, si el testimonio tiene valor informacional es sometido a crítica, pero si el contenido o partes de él carecen de ese valor informacional, se

59 Páez, Andrés. "La prueba testimonial y la epistemología del testimonio.» Isonomía 40, Abril 2014: 95 $-118$.

60 Decastro González, Alejandro. «Admisibilidad y valor probatorio de las declaraciones anteriores del testigo.» Revista Internacional de Derecho Penal Contemporáneo, 2009: 37 - 94. Bedoya Sierra, LuIs Fernando. La prueba en el proceso penal colombiano. Bogotá: Fiscalía General de la Naciòn, 2008.

61 Bustamante Rúa, Mónica, y Diego Palomo Vélez. «La presunción de inocencia como regla de juicio y el estándar de prueba de la duda razonable en el proceso penal. Una lectura desde Colombia y Chile.» lus et Praxis vol. 24 No. 3, 2018: 651 - 692.

62 PÁez, Andrés. "La prueba testimonial y la epistemología del testimonio.» Isonomía 40, Abril 2014: $95-118$. 
acepta de manera automática. Este tipo de análisis tiene relevancia para desechar las críticas de los negacionistas del holocausto, simplemente porque el testigo se equivoca en aspectos no fundamentales del testimonio. $Y$ genera también bases para la discusión de los testigos inauténticos, que hacen relatos verdaderos sobre eventos en los que nos han tomado parte. En estos casos, su testimonio debe ser tratado como uno de oídas, y, por ello, con poco valor probatorio. ${ }^{63}$

El relato de las víctimas es el eje de los estudios de la memoria, lo que ha conducido a una suerte de eternización del presente, en donde este relato sustituye al del historiador y el tiempo presente se convierte en el horizonte dominante de la memoria. ${ }^{64}$ Los procesos judiciales como mecanismos de justicia transicional contribuyeron al ascenso del testigo, incluso en el juicio de Núremberg en donde la crudeza de las imágenes de los campos de concentración liberados no fue suficiente, la dimensión del horror solo se alcanzó con los relatos de las víctimas. ${ }^{65}$

El testimonio lleva la impronta de un tipo de relato estructurado en primera persona, que daba cuenta de una experiencia apremiante, vivida en carne propia 0 en proximidad. La enunciación del testimonio ha brindado voz pública a quien carece de ella, sea por razones de exclusión política 0 debido a la marginación del ámbito alfabetizado. ${ }^{66}$

El testimonio se convierte así en un acto de la memoria, pues su validez depende del hecho de que es el único que ha presenciado los hechos, es el portador de un vestigio. Acude a la validación de lo que dice por su propia presencia, y si no le creemos podemos preguntar a otro testigo (con lo que ello supone de violación de las premisas de un modelo reduccionista). Al sustituir la memoria a la historia, los criterios ya no están dados por una teoría de la verdad-como correspondencia 0 como consenso- sino por la fiabilidad, esto es, el relato del testigo toma el lugar de la verdad y de una tesis reduccionista pasamos a una anti - reduccionista.

63 Cercas, Javier. El Impostor. Barcelona: Penguin Random House, 2014.

64 Bustos, Gerardo. "La irrupción del testimonio en América Latina: intersecciones entre historia y memoria.» Historia Crítica No. 40 Dossier Memoria, Historia y Testimonio en América Latina, Enero Abril 2010: 10 - 19.

65 Pongo al testigo y al testimonio en cursivas, pues técnicamente no es un relato sobre el hecho de un tercero, sino uno sobre algo que le sucedió como víctima. Sin embargo, en los diferentes estudios de memoria y de justicia transicional no se distingue entre el relato de la víctima o del victimario y el testimonio. Todos estos relatos son presentados como testimonios.

66 Bustos, Gerardo. "La irrupción del testimonio en América Latina: intersecciones entre historia y memoria.» Historia Crítica No. 40 Dossier Memoria, Historia y Testimonio en América Latina, Enero Abril 2010: 10 - 19. 


\section{La verdad, el testigo y la memoria}

El pasado busca ser conocido, entre otros medios de prueba, a través de las palabras del testigo. Sin embargo, con respecto a la memoria histórica es cada vez más escasa la posibilidad de contar con testimonios orales de las víctimas, con el contacto cara a cara y con la conversación con ellos y ellas para que nos cuenten sus experiencias. ${ }^{67}$ Por ello el testimonio termina siendo reemplazado por el documento, ya sea testimonios grabados o testimonios escritos, o como en el caso de Jorge Semprún e Imre Kertesz, entre muchos otros, por relatos novelados de la experiencia de la victimización, en su caso el campo de concentración. ${ }^{68}$

La idea del testigo nos remite a la relación entre el testigo y la justicia. La justicia se define como el recuerdo institucionalizado del pasado. ${ }^{69}$ Ese es un recuerdo que se da dentro del proceso judicial, pero para que pueda ser recordado el testigo debe estar diciendo la verdad, es decir, su testimonio está conformado por

67 Finkielkraut, Alain. La memoria vana. Del crimen contra la humanidad. Barcelona: Anagrama, 1990.

68 En Primo Levi, Jorge Semprún y Jean Amery encontramos la idea del testigo que relata lo que ha visto y que con su relato nos deja conocer lo más profundo del dolor humano. Sin embargo, los textos de estos autores representan diferentes formas de hacer ese relato.

Para Levi, se trata de ser el testigo por excelencia, el que observa y toma nota de lo que sucede; el que da cuenta de lo visto, como un científico describe a la naturaleza. Por ello Levi señala que “creo en la razón y en la discusión como supremos instrumentos de progreso y por ello antepongo la justicia al odio. Por esta misma razón, para escribir este libro he usado el lenguaje mesurado y sobrio del testigo no el lamentoso lenguaje de la víctima ni el iracundo lenguaje del vengador: pensé que mi palabra resultaba tanto más creíble cuanto más objetiva y menos apasionada fuese; solo así el testigo en un juicio cumple su función, que es la de preparar el terreno para el juez. Los jueces sois vosotros" (Levi 2005, 303). En Amery y Semprún el testigo no aparece simplemente para relatar lo sucedido. Tanto uno como otro se tomaron mucho tiempo (20 y 50 años respectivamente) para contar sus experiencias. En Amery la experiencia no es un relato de los acontecimientos como en Levi, sino un relato que es a la vez denuncia y reflexión filosófica (Amery 2004). En el caso de Semprún la cuestión es mucho más complicada, pues este autor considera que la única forma de relatar lo sucedido es acudiendo a la ficción. Pero esto no lo hace para falsear los acontecimientos, sino para tomar una distancia que le permita sobrevivir a la experiencia de contar. Así lo señala Semprún cuando afirma que no pretende un testimonio: “De entrada, quiero evitarlo, evitarme la enumeración de los sufrimientos y los horrores. De todos modos, siempre habrá alguno que lo intente...Ni siquiera deseo meterme por este camino. Necesito pues un "yo" de la narración que se haya alimentado de mi vivencia pero que la supere... Una ficción que sería tan ilustrativa como la verdad, por supuesto. Que contribuiría a que la realidad pareciera real, a que la verdad fuera verosímil" (Sánchez 2008, 8). Los tres autores coinciden en que el único testigo verdadero es aquél que no abandonó el campo de concentración, pues solo él o ella pudieron conocer la realidad hasta sus últimas consecuencias. Por ello, como lo señala Sánchez (Sánchez 2008, 15), existe un temor a ser más un impostor que un testigo.

69 Bоотн, W. James. "The unforgotten: Memories of Justice.» The American Political Science Review Vol. 95 No. 4 (December), 2001: 777 - 791. 
enunciados que deben concordar con la realidad para que podamos predicar de ellos su carácter de verdaderos (verdad como correspondencia). Pero la verdad se obtiene con un propósito, el de sacar consecuencias normativas mediante la imposición de una sanción.

Un aspecto poco analizado en el campo de la justicia transicional es el de las diferencias en el uso y la confianza en el testigo dentro de los procesos ordinarios y en los procesos transicionales. En el proceso penal la confesión, o sea el relato del acusado, era el medio de prueba propio de los procesos inquisitivos, en los cuales se llegaba incluso a la tortura al mismo para que relatara todo o para que confesara todos sus delitos si era el acusado. Por ello en el desarrollo de las garantías penales se establece el derecho de las personas a no declarar en su contra o en contra de sus parientes más cercanos. Como consecuencia de ello, en los procesos penales se acude a otro tipo de medios de prueba más técnicos y que garanticen la mayor objetividad posible en la determinación de la responsabilidad. ${ }^{70}$

El testigo es un narrador de historias, se supone que dado su conocimiento de los hechos haga un relato de estos. ${ }^{71}$ El testigo en el derecho colombiano debe comenzar con un relato espontáneo de los hechos y posteriormente la historia se va componiendo gracias a las preguntas de las partes. Existe una obligación de decir la verdad, por lo que, como lo comentábamos antes, su historia debe ser verídica y, en principio, se presume verídica. Pese a que son aportados por una de las partes en conflicto no están obligados a mentir para tomar el punto de vista de quien los lleva, aunque Taruffo reconoce que en ello hay una tensión. Como lo señala Taruffo, del testigo "se espera - y se le obliga a hacerlo- que narre una historia verdadera. También esta narración pertenece a la categoría de los actos ilocucionarios asertivos, al estar compuesta de enunciados que describen hechos, y tiene la función de proporcionar al juez informaciones verdaderas y fiables".72

Sin embargo, la decisión sobre la verdad no la toma el testigo -que debe aportarla o lo que él considera que es la verdad- sino el juez, que hace la narración última de los hechos en la sentencia, en los hechos probados que, en tanto probados, se consideran verdaderos. ${ }^{73}$ La narración debe ser motivada, es decir aportando las razones para que las partes conozcan cuál es la verdad que queda probada de

70 Taruffo, Michele. La prueba de los hechos. Madrid: Trotta, 2002.

71 Taruffo, Michele. Simplemente la verdad. El juez y la construcción de los hechos. Barcelona: Marcial Pons, 2010.

72 Ibíd.

73 Ibíd. 
los hechos -y la que será la verdad pública del mismo - y los elementos que la fundamentan. Como lo concluye Taruffo,

si...la motivación de los hechos existe efectivamente, es completa y coherente, entonces se puede decir que la narración de los hechos construida por el juez cuenta con una válida justificación racional, en la medida que resulta confirmada por el análisis crítico de todas las pruebas disponibles. En este sentido, se podrá decir que enuncia la verdad. ${ }^{74}$

En los procesos de justicia transicional el testimonio resulta relevante, como parte del reconocimiento de la dignidad de las víctimas, a las que por vez primera se les da la posibilidad de hablar de lo que ha sucedido, pero también como parte de la necesidad de que los victimarios reconozcan los hechos y asuman la responsabilidad por los mismos. Es decir, al contrario de lo que se señala en el derecho penal ordinario, en los procesos transicionales la declaración en contra de uno mismo es uno de los ejes fundamentales del proceso. La narrativa que se construye por parte del juez es el resultado de un proceso de negociación de la verdad y, por tanto, en muchos casos depende de razones más políticas que epistémicas. Es llamativa la conclusión a la que llega Taruffo en un texto reciente. En este texto analiza el proceso de justicia transicional colombiano y su relación con la verdad y muestra, de manera interesante, que el proceso transicional colombiano tiene una finalidad política de cierre del pasado, pero no una epistémica y jurídica de conocimiento de la verdad:

Es un sistema tan complejo, y tan analíticamente regulado, que cualquier evaluación sumaria debería evitarse. Sin embargo, vale la pena enfatizar lo que parece ser el aspecto más relevante de este sistema. Como dijimos, el acuerdo habla de la búsqueda de la verdad sobre las responsabilidades de los perpetradores de los crímenes, incluso si la verdad considerada por mucho la más importante es la concerniente a las víctimas. Por otro lado, la verdad sobre la responsabilidad depende esencialmente de su reconocimiento. El punto crítico, entonces, es que no existe un mecanismo de control y verificación sobre la veracidad del reconocimiento, ni prueba de los hechos que son "reconocidos". La consecuencia parece obvia: el reconocimiento puede ser incompleto, construido ad hoc o completamente falso, y llevado a cabo con el único propósito de obtener una escasa penalización. De ahí la duda de si estos mecanismos están realmente 
dirigidos al descubrimiento de la verdad, o no están más bien orientados a cerrar un conflicto en nombre de una verdad que se proclama en palabras pero que de hecho se considera como poco relevante. ${ }^{75}$

Los procesos de memoria también se basan con frecuencia en los testimonios de los supervivientes, al punto que autores como Elie Wiesel en relación con el holocausto consideran que sólo los sobrevivientes tienen derecho a relatar el pasado, a dejar un testimonio válido de lo sucedido (Wiesel 1986). Otros elementos como las películas o las fotografías son solo acompañantes del testimonio, como si la verdad sólo pudiera ser tal si es dicha por una víctima, excluyéndose de ese modo a los testigos -terceros- ${ }^{76}$

Alejandro Baer analiza las diferentes formas de hacer memoria del holocausto, destacando cómo los medios de comunicación y las tecnologías actuales han llevado a un replanteamiento de los límites de la representación del holocausto, pues obras como "La Lista de Schindler", de Steven Spielberg, tienen mucho más efecto en la transmisión de la memoria que los relatos de los supervivientes y que las producciones museísticas, ello incluso a pesar de los riesgos de estetizar el horror. Como lo señala Wiesel, citado por Baer, "Auschwitz es algo de una naturaleza diferente, un misterio apartado de la historia, que no puede ser comprendido y por ello plantea retos irresolubles a su representación".77 Más adelante afirma, "hay verdades que pueden ser comunicadas por la palabra; hay verdades más profundas que solo pueden ser transmitidas por el silencio; y, en otro nivel, están aquellas que no pueden ser expresadas, ni siquiera por el silencio. Y, aun así (...) deben ser comunicadas" (Baer 2006, 102).

La búsqueda de una forma de representación que respete los límites de la prohibición de imágenes parece encontrarse en el relato/testimonio del superviviente. La explosión del uso de relatos en los procesos transicionales parece llenar el vacío dejado por la prohibición de imágenes y a la vez responder a los imperativos de la memoria. ${ }^{78}$ Es característico de estos análisis la confusión entre testigos y víctimas,

75 Taruffo, Michele. «Proceso y Verdad en la Transición.» Derecho y Sociedad No. 50, 2018: 295 - 306

76 Sánchez - Bıosca, Vicente. Cine y Guerra Civil. Del mito a la memoria. Madrid : Alianza, 2006. Labanyı, Jo. "El cine como memoria. La memoria del cine.» En Plan Rosebud. Sobre imágenes, lugares y políticas de la memoria, de María (ed) Ruido, 471 - 484. Santiago de Compostela: Xunta de Galicia/Centro Galego de Arte Contemporánea, 2008.

77 Baer, Alejandro. Holocausto, Recuerdo y Representación. Madrid: Losada, 2006.

78 Ibíd. 
como si la víctima pudiera convertirse en un tercero cuando habla de su propia historia. Para Baer:

Los testimonios serían así un intento de registrar y recuperar las huellas de un desastre que en sí mismo resiste toda representación y puede ser solamente captado mediante el encuentro con sus efectos en quienes sobrevivieron. El testimonio está investido además de la autoridad del testigo presencial, una de las fuentes que instauran la verdad histórica, al mismo tiempo que posee el poder evocativo de todo relato personal. Podemos decir así que el testimonio plantea una salida productiva a los problemas mencionados. Se sitúa a medio camino entre historia (0 historiografía) y literatura, entre memoria y arte. Este rasgo ambivalente, entre objetividad y expresividad, entre lo literal y lo poético, tal vez constituya su verdadera fuerza para dar cuenta de las realidades del Holocausto. Las posiciones mencionadas coinciden en un tercer aspecto relacionado con la representación histórica: el Holocausto solo puede ser contado desde una perspectiva. La de sus víctimas. ${ }^{79}$

El filósofo italiano Giorgio Agamben analiza la situación del testigo en el campo de concentración y muestra cómo se da una laguna en el testimonio y una paradoja. Pues quien estuvo en las cámaras de gas no puede testimoniar de su existencia y si lograra hacerlo pondría en cuestión su propio testimonio. Para Agamben la imposibilidad del testimonio se encuentra en la figura del musulmán, aquél que perdió toda esperanza de vida y que finalmente sucumbió. Para Agamben el testimonio es imposible en estas situaciones. ${ }^{80}$ Agamben cita a Levi afirmando lo siguiente:

Hay también otra laguna, en todo testimonio: los testigos, por definición son quienes han sobrevivido y todos han disfrutado, pues, en alguna medida, de un privilegio...El destino del prisionero común no lo ha contado nadie, porque, para él no era materialmente posible sobrevivir...El prisionero común también ha sido descrito por mí, cuando hablo de "musulmanes" pero los musulmanes no han hablado (...) Los que no han vivido esa experiencia nunca sabrán lo que fue; los que la han vivido no la contarán nunca; no verdaderamente, no hasta el fondo. El pasado pertenece a los muertos... ${ }^{81}$

79 Ibíd.

80 Agamben, Giongio. Lo que queda de Auschwitz: el archivo y el testigo. Homo Sacer II. Valencia: Pre Textos, 2010.

81 Ibíd. 
Tradicionalmente se acude al testigo porque tiene una experiencia directa de los hechos y, por tanto, nos pueda dar cuenta de lo sucedido. Por ello en el derecho probatorio los testimonios de oídas -el hearsay- no son admitidos, pues de lo único que nos informan es que el testigo sabe que otra persona dijo algo, pero en realidad no puede informar de los hechos objeto de investigación. Sin embargo, en los estudios de la memoria el relato del testigo directo es crucial. Por ello Agamben hace la aclaración de aquello sobre lo que puede informar y por ello afirma que el testigo del último momento de horror no existe, pues o no presenció realmente las cámaras de gas 0 está muerto pues pereció en ellas. Pero esto nos deja con un problema fundamental, si el pasado solo pertenece a los muertos, no cabe alcanzar la verdad última en los procesos transicionales sino solo aproximaciones a la verdad. Sin embargo, en el proceso judicial se sabe que la verdad es relativa y que la construcción del relato verdadero debe hacerse a través de muchos medios de prueba, incluso apelando a la inferencia lógica a partir de hechos debidamente probados.

Un caso especial en los estudios de la memoria y en esa relación entre testimonio y memoria son los impostores del holocausto o de los campos de concentración. Para los negacionistas esta es una prueba de que el Holocausto no existió. Pero la cuestión es mucho más compleja, pues de lo que se trata es de hechos que están completamente documentados pero cuyo testigo es falso. En la historia del holocausto han surgido varios testigos falsos de hechos ciertos. Norman Filkenstein analiza un caso en el que se da un relato conmovedor del holocausto, pero sin que el sujeto haya estado en un campo de concentración o fuera judío. La respuesta de Elie Wiesel a ese caso en particular es interesante. Para Wiesel, se trata de un sujeto que transmitió la experiencia del Holocausto tal como las víctimas la vivieron, y que el hecho de que no lo haya vivido no afecta para nada la vivencia de ese dolor. ${ }^{82}$

En España en el año 2005 surgió la discusión alrededor de la figura de Enric Marco, un anarquista catalán que reconfiguró su pasado para presentarse como resistente al franquismo, como víctima de los Nazis y como sobreviviente de un campo de concentración. Marco era el presidente de la Amical de Mauthausen, una de las organizaciones que albergaba a los españoles sobrevivientes de estos campos y se presentaba como una víctima del Nazismo. Las inconsistencias en su relato llevaron a que la investigación realizada por el historiador Benito Bermejo mostrara que Marco mentía y pusiera en evidencia el hecho de su viaje voluntario a Alemania y, por extensión, la posibilidad de que no hubiera estado en un campo de concentración. ${ }^{83}$

82 Finkielkraut, Alain. La memoria vana. Del crimen contra la humanidad. Barcelona: Anagrama, 1990.

83 Cercas, Javier. El Impostor. Barcelona: Penguin Random House, 2014. 
Lo interesante del caso Marco es la respuesta al mismo. Por una parte, Marco considera que ha contribuido con un relato sobre los hechos, y que en últimas él simplemente es el vehículo de comunicación de quienes no pueden narrar su historia. Aquí el falso narrador destaca la verdad de su relato. Por su parte, quienes lo atacaron consideraron que al mentir afectaba a las víctimas del Nazismo y se burlaba de su condición. El escritor Javier Cercas escribe un libro en el que analiza el caso de Marco y en el que se ocupa de la cuestión de la memoria histórica y de lo que él denomina la industria de la memoria. Cercas considera que el relato de Marco no afecta la verdad del Holocausto, que está bien documentada y que no admite discusión ${ }^{84}$, pero sí es una prueba del Kitsch de la memoria, aquel uso edulcorado de la memoria para conmover y no para informar. ${ }^{85}$

Para Cercas, esto es el resultado de las confusiones entre la memoria y la historia. Criticando el concepto de memoria histórica y lo que él llama la tiranía de la memoria, este autor afirma:

Pero la historia no puede estar al servicio de la memoria, sino de la verdad, y la memoria es por definición lo opuesto a la verdad, porque es parcial, personal, subjetiva, mientras que la historia debe aspirar a ser, si no total y universal, sí al menos objetiva. La memoria es un ingrediente de la historia, no la historia: uno de los riesgos de convertir la memoria en historia -uno de los riesgos de las llamadas Leyes de Memoria- consiste en la creciente inclinación a escribir la historia desde el punto de vista exclusivo de las víctimas, cuando la historia de las víctimas es apenas una parte de la historia, que sólo empieza a completarse con la historia de los verdugos: una no existe sin la otra, ni se explica sin la otra. La historia pierde así su función de reconstructora objetiva del pasado al subordinarse a la memoria; la propia memoria pierde su función de vínculo vivo con la reivindicación de justicia que la anima, de recurso de los vencidos de la historia, y al institucionalizarse puede convertirse en la coartada del terror. $^{86}$

84 Ibíd.

85 El impostor o el falso narrador no se diferencia de los novelistas que recrean los hechos del pasado para que se adecuen a sus argumentos. Sin embargo, en la novela sabemos que el escritor nos hace un guiño y nos dice esto que afirmo pudo haber sido así, o pudo haber sido de otra manera. En la vida "real" los recursos de la novela no están permitidos y por ello se le denomina engaño. Tal es la línea que cruzar el impostor, pese al hecho que su relato sea verdadero (Cercas, El Impostor 2014) (J. Habermas 1990).

86 Cercas, Javier Cercas. "La tiranía de la memoria.» El País, 2 de Enero de 2008: 1. 
Este es un análisis interesante, pero muestra precisamente una visión conservadora de la historia. En esta crítica se desconoce que la historia no es objetiva, que es un relato construido y que en muchas ocasiones hace de la memoria la base para la construcción del relato histórico. En la memoria se parte de la experiencia de lo vivido, que puede ser comunicable a otros, aunque quede como una vivencia personal:

Por partir de la experiencia directa, la memoria es múltiple como lo son las vivencias mismas. Por ello, parece más adecuado hablar de las memorias, en plural, que de una memoria única. La multiplicidad de experiencias da lugar a muchos relatos distintos, contradictorios, ambivalentes que el ejercicio de memoria no trata de estructurar, ordenar ni desbrozar para hacerlos homogéneos o congruentes. Por el contrario, su riqueza reside en permitir que conviva lo contrapuesto para dejar que emerja la complejidad de los fenómenos, pero también para abrir paso a diferentes relatos. De esta forma, la memoria no se arma como un rompecabezas, en donde cada pieza entra en un único lugar, para construir siempre la misma imagen; sino que opera a la manera de un lego, dando la posibilidad de colocar las mismas piezas en distintas posiciones, para armar con ellas no una misma figura sino representaciones diferentes cada vez. Es por ello por lo que, en esta clase de construcción, no puede haber un relato único ni mucho menos dueños de la memoria. ${ }^{87}$

La memoria no arranca desde el pasado, sino que se dispara desde el presente y se lanza al pasado. Son las preocupaciones del presente las que trae el pasado y las que lo usan para la configuración del futuro. La fidelidad de la memoria reclama que se recupere el sentido que el pasado tuvo para sus protagonistas y, al mismo tiempo, que se descubran los sentidos que esa memoria pueda tener para el presente. Así la memoria funciona como un gozne que articula pasado, presente y futuro. Pero la memoria puede ser oficial o subalterna, puede ser parte del archivo o no haber llegado a él. Esto lo muestran Rosón y Lucas cuando analizan las memorias de las mujeres, que son excluidas y que con frecuencia son silenciadas. Estos materiales facilitan una reflexión política sobre el tiempo, pues denuncian lo que se recuerda y el espacio y territorio en donde ello ocurre. ${ }^{88}$

87 Calveiro, Pilar. "Los usos políticos de la memoria.» En Sujetos sociales y nuevas formas de protesta, de Gerardo, comp Caetano. Buenos Aires: CLACSO, 2006.

88 FabRI, SILVINA M. «Lugares de memoria y marcación territorial: sobre la recuperaciòn de los centros clandestinos de detenciòn en Argentina y los lugares de memoria en España.» Cuadernos de Geografía 


\section{Memoria y Verdad}

En esta sección analizaré la cuestión de la memoria y su relación con la verdad. En primer lugar, es preciso distinguir entre la verdad proporcionada por el proceso judicial, por la historia y por la memoria. Las dos primeras quieren mostrar la concordancia entre sus enunciados y los del mundo real. El proceso judicial adopta una verdad en la cual el enunciado fáctico " $\mathrm{X}$ mató a $\mathrm{Y}^{\prime}$ " debe ser verdadero para poder concluir con el enunciado normativo " $X$ es responsable de la muerte de $Y$ ", $Y$ por tanto para poder sacar las consecuencias necesarias que permitan afirmar " $X$ merece la pena Z". Los enunciados de la historia varían un poco, pero no renuncian a hacer afirmaciones fácticas del tipo "X mató a $Y$ en la batalla $Z$ ", pero sí se sale de su campo cuando hace afirmaciones de responsabilidades normativas en los que se usen enunciados de deber ser ${ }^{89}$ Esto no es obstáculo para que se dé una historia crítica, pero ella debe darse dentro de los marcos propios de la disciplina.

La memoria por el contrario parte de la base de los recuerdos de las personas 0 de las sociedades. Ella no pretende afirmar hechos sino recordarlos, y el olvido no es un error cognoscitivo sino parte del proceso de selección que hace la memoria. Las víctimas tienen un derecho a la memoria, pero también uno al olvido. Sin embargo, las generaciones futuras sí tienen un deber de recordar. ${ }^{90}$ La pregunta es, sin embargo, ¿qué es lo que recuerdan? ¿Los hechos del pasado? 0, ¿los recuerdos de otros -de los testigos- de manera que nuestro propio recuerdo es un recuerdo del recuerdo y el olvido de otros? Si es así, ¿cuál es el valor práctico de la memoria para los procesos de justicia transicional? En las siguientes secciones me ocupo de analizar la cuestión de la memoria, el olvido y el testimonio. ${ }^{91}$

Como consecuencia del Holocausto, en Alemania y en otros países de Europa se comenzaron a desarrollar políticas de la memoria. Es decir, los gobiernos implementaron políticas públicas para cumplir con su deber de no olvidar. Pero estas políticas no buscan establecer la verdad sobre el pasado, sino recordar un pasado

vol.22 No. 1 (Enero - Junio), 2013: 93 - 108. Rosón, María, y R. Lucas Platero. «Fantasmas, Género, Memoria y Políticas Públicas en la Reciente Historia Española.» En Polítiques de Memòria, Gènere i Ciutat, de Maria de la Fuente (coord), 8 - 34. Barcelona: Institut de Ciències Polítiques i Socials, 2017.

89 HaACK, Susan. "Truth, Truths, "Truth", and "Truths" in the Law.» 26 Harvard Journal of Law and Public Policy, 2003: 17 - 21. Vera Sánchez, Juan Sebastí́n. "Cuatro mitos sobre la justicia retributiva como mecanismo de justicia transicional.» 32 American University International Law Review 469, 2016 2017: 469 - 499 .

90 Augé, Marc. Las formas del olvido. Barcelona: Gedisa, 1998.

91 Asн, Tiмотнy Garton. «The Truth About Dictatorship.» The New York Review of Books, 1998. 
que ya se asume conocido y cuya verdad (la de los enunciados fácticos sobre él) ya han sido demostrados por la historia o por el proceso judicial (normalmente penal). ${ }^{92}$ Pero el pasado puede también se normalizado o domesticado, esto es, depurado de los enunciados más problemáticos, con el fin de facilitar la transición hacia la democracia o hacia la paz. ${ }^{93}$

Si bien es cierto que los individuos recuerdan los acontecimientos, son los grupos sociales los que determinan qué es memorable y cómo aquello que merece ser recordado es efectivamente recordado. Los individuos se identifican con acontecimientos importantes para su grupo, incluso con cosas que no han experimentado directamente. ${ }^{94}$ La memoria no es necesariamente por hechos aprehendidos de primera mano -esto es no estamos hablando de testigos del acontecimiento-, pero sí por sujetos que recuerdan los recuerdos de otros, que tienen memorias de memorias alejadas en el tiempo y que por ello se denomina memoria histórica.

Las memorias individuales de quienes han vivido directamente un suceso determinado, al interrelacionarse con las de otros individuos con los que se comparte algún tipo de adscripción social o cultural, contribuyen a crear un relato compartido (memoria colectiva o social), que será transmitida a las generaciones venideras (memoria histórica). ${ }^{95}$

No se trata de la discusión de Wiesel sobre la imposibilidad de dar testimonio sobre lo no vivido, sino de la capacidad de las sociedades de enfrentar su pasado a partir del recuerdo de otros. Esto es, del tránsito de la memoria individual a la memoria histórica.

Los estudios de la memoria con frecuencia se han basado en la tradición judía y en la afirmación de Adorno de que después de Auschwitz no es posible hacer poesía. Igualmente se suele hacer referencia a la obra de Benjamin y la idea de la memoria del sufrimiento, esto es, el reconocimiento de la relación entre el presente y el pasado

92 Agullar Fernández, Paloma. Políticas de la memoria y memorias de la política. El caso español en perspectiva comparada. Madrid: Alianza Editorial, 2008.

93 Olick, Jefrerey K, y Joyce Robbins. "Social Memory Studies: from "collective memory" to the historical sociology of mnemonic practices.» Annual Sociological Review Nro. 24, 1998: 105 - 140. OLICK, JefFrey K. «Memory and the Nation: continuities, conflicts, and transformations.» Social Science History Vol. 22 No. 4, Winter 1998: 377 - 387.

94 Aguilar Fernández, Paloma. Políticas de la memoria y memorias de la política. El caso español en perspectiva comparada. Madrid: Alianza Editorial, 2008.

95 Ibíd. 
y el gozo del presente gracias al sufrimiento de las víctimas del progreso ${ }^{96}$ Por su parte, en la literatura posterior al holocausto se asume la posición del testigo, como lo señalan Levi y Agamben ${ }^{97}$ En todos estos estudios la cuestión de la memoria es central, y se destaca la importancia de conservar sus vestigios -como en Nora- 0 de conservar los relatos de los testigos de los acontecimientos -como en Levi, Agamben y Wiesel. ${ }^{98}$

Para el premio Nobel de literatura Elie Wiesel, el Holocausto no puede ser objeto de la ficción, solo puede ser escrita por aquellas personas que la han vivido, pues la crueldad del exterminio no puede ser objeto de una elaboración estética. ${ }^{99}$ En esto difiere de la posición de Jorge Semprun, quien sostenía en una entrevista que frente a la muerte de los sobrevivientes del Holocausto era necesario que una nueva generación se ocupara de escribir sobre el tema. ${ }^{100}$ Posteriormente, en una entrevista para su biógrafa Franziska Augstein, se acerca un poco más a la posición de Wiesel sobre la imposibilidad de escribir sobre el holocausto sin haber sido un testigo directo del mismo.101 Sin embargo, esta es una posición que es insostenible en el largo plazo pues una vez muertos todos los sobrevivientes el único destino es el olvido, pues los textos quedaran como testimonios muertos que ya no le dicen nada a las comunidades de significado actuales. El punto de vista común a todo esto es que el relato verdadero, que merece toda nuestra atención y que no puede ser cuestionado, es el del testigo directo, quien con el valor simbólico de su experiencia es el que le da poder veritativo a su recuerdo. En síntesis, es una justificación del enunciado "lo que recuerdo es cierto porque yo, que soy un sobreviviente, lo recuerdo"

Desde el punto de vista de las ciencias de la comunicación, Rosa-Auria Munté Ramos analiza la literatura del holocausto y muestra cómo se ha pasado de un relativo olvido del mismo con posterioridad a la guerra; a un conocimiento y

96 Baer, Alejandro. Holocausto, Recuerdo y Representación. Madrid: Losada, 2006. Mate, Manuel Reyes. Tratado de la Injusticia. Barcelona: Anthropos, 2011.

97 Agamben, Giongio. Lo que queda de Auschwitz: el archivo y el testigo. Homo Sacer II. Valencia: Pre Textos, 2010. Levi, Primo. Trilogía de Auschwitz. Barcelona: El Aleph, 2005.

98 Olick, Jefrerey K, y Joyce Robilns. "Social Memory Studies: from "collective memory" to the historical sociology of mnemonic practices.» Annual Sociological Review Nro. 24, 1998: 105 - 140.

99 Munté, Rosa Auria. La ficción sobre el Holocausto: silencio, límites de representaciòn y popularización en la novena Everything is IIluminated de Jonathan Safran Foer. Tesis Doctoral. Barcelona: Universidad Ramón Llull, 2011.

100 https://www.youtube.com/watch?v=7 _ QmLezLoy8 Última visita 9 de enero de 2018.

101 Augstein, Franziska. Lealtal y traición. Jorge Semprún y su siglo. Barcelona: Tusquets, 2010. 
discusión posterior acerca de la imposibilidad de la ficción, en una segunda etapa; para luego pasar a la tercera etapa, en la que se americaniza y se populariza y, como industria cultural, se exporta al resto de la cultura occidental. ${ }^{102}$ Siguiendo a Dominick LaCapra, Munté afirma que hay tres tipos de aproximaciones a la representación del Holocausto -y de cualquier acontecimiento límite-: el del testigo, el de la ficción, y el de la historia. Cada uno construye su propia narrativa y sus propias pretensiones de fiabilidad.

El relato del testigo se caracteriza porque hace reclamos desde la experiencia 0 , al menos, desde el recuerdo que tiene de ella. Su relato no hace un reclamo de realidad sino evidencia experiencial. ${ }^{103}$ Por su parte, la narración histórica hace reclamos de realidad sobre los acontecimientos, su interpretación y su explicación. Puede basarse en los testimonios de las víctimas, pero no se identifica con el relato del testigo. Y, en tercer lugar, el relato de la ficción indaga otras formas de experiencia posible y aborda los aspectos emocionales y afectivos de la experiencia. ${ }^{104}$ Esta autora llama la atención sobre la importancia de cada perspectiva, pero también advierte que debemos tener en cuenta los puntos de intersección entre uno y otro.

La opción del silencio absoluto es restrictiva en exceso, y por eso la necesidad de decir se impone. El miedo al silencio absoluto hace que el argumento de la irrepresentabilidad evolucione y se concrete en otro aspecto también importante: desde posiciones académicas igualmente restrictivas se acepta la narración del Holocausto, pero no cualquier tipo de narración. El Holocausto se puede contar desde el punto de vista del historiador, por ejemplo, pero se razona que la ficción es un límite infranqueable y no se acepta la posibilidad de representación desde la imaginación, como expone Wiesel. ${ }^{105}$

102 Munté, Rosa Auria. La ficción sobre el Holocausto: silencio, límites de representaciòn y popularización en la novena Everything is Illuminated de Jonathan Safran Foer. Tesis Doctoral. Barcelona: Universidad Ramón Llull, 2011.

Este en un análisis similar al de Alvin Rosenberg, quien habla de la saturación del holocausto (Rosenberg 2011).

103 Cercas habla del chantaje del testigo que parece invalidar cualquier otro tipo de experiencia. Parece que solo el testigo puede hablar del acontecimiento y los demás están en posición de escucharlo. Este análisis se hace a propósito del escándalo de Enric Marco y su invención como una víctima de los campos de concentración (Cercas 2014).

104 Munté, Rosa Auria. La ficción sobre el Holocausto: silencio, límites de representaciòn y popularización en la novena Everything is Illuminated de Jonathan Safran Foer. Tesis Doctoral. Barcelona: Universidad Ramón Llull, 2011.

105 Ibíd. 
Sin embargo, como lo muestra Munté, se hace ficción, y mucha, del Holocausto. Se ha pasado por tres etapas: silencio sobre el pasado, conocimiento sobre el Holocausto e inicio de una reflexión académica sobre el mismo y, desde los años 1980s, posterior a la serie "Holocausto" con Meryl Streep, la popularización y la conversión del Holocausto como un producto de consumo de masas. Esto es importante, porque la memoria que se tiene del Holocausto sustituye al testigo por el producto cultural, incluso si el producto cultural se basa en su propio relato. De esta manera, la cuestión ya no es sobre la verdad de lo que se recuerda -que queda fuera de disputa- sino sobre la mejor forma de hacerlo conocer. Pero la reacción negativa de Wiesel a la serie nos muestra que en todo caso el testigo directo sigue reclamando para sí la determinación de valor de verdad que desde la serie se emiten. Es decir, si era posible reír en el campo de concentración no puede ser simplemente una licencia poética, sino que debe ser estrictamente cierto para no afectar a la memoria del holocausto. ${ }^{106}$

La memoria se ocupa del pasado, pero no puede simplemente inventarlo. Como en el proceso judicial y en la historia, la memoria tiene que tener un cierto contenido de verdad, así se trate de una verdad relativa. La afirmación "yo recuerdo que sucedió de esta manera" tiene que basarse en ciertos hechos para que sea verdadera: en primer lugar, está el hecho que la persona debe haber sido testigo del acontecimiento, si está reclamando un conocimiento directo. La afirmación de su recuerdo será falsa si no lo presenció, como en el caso de Enric de Marco. En segundo lugar, el relato debe ser verosímil, debe ser acorde con el contexto, debe ser creíble y contrastable con lo que dicen otras fuentes. La memoria, en suma, no puede alejarse de la verdad, al contrario de los que afirma Cercas, la memoria se basa en diferentes contenidos de verdad, tan parcial como la que brinda el proceso judicial y sometida a sus propios controles para evitar las imposturas. Se trata de una verdad como correspondencia, pues para que la memoria sirva de mecanismo de justicia transicional no puede ser el simple recuerdo distorsionado de lo que pasó, sino que debe ser un recuerdo ajustado a lo que pasó. De esta manera memoria e historia se complementan, y en su ayuda -como fuente- acude en ocasiones el proceso penal.

106 Ver http://archives.chicagotribune.com/1978/04/19/page/32/article/trivializing-the-holocaust-semifactand-semifiction y sobre la película italiana "La vida es bella" ver http://elpais.com/diario/2007/10/27/ babelia/1193442611_ 850215.html .Última visita 16 de febrero de 2015. 


\section{La Confesión Judicial y la Memoria}

La justicia transicional tiene como objetivo final garantizar que los hechos victimizadores no se repitan. Por ello es tarea del Estado desarrollar una serie de políticas que permitan que las víctimas recuperen sus proyectos de vida y crear las condiciones para que esos proyectos puedan realizarse. Si bien el daño causado con las violaciones de las que se ocupan los procesos de justicia transicional es irreparable, el Estado sí puede tomar medidas para garantizar su no repetición. ${ }^{107}$

Para poder aplicar justicia y para poder reparar es necesario conocer la verdad de lo acontecido. Incluso el perdón depende de la verdad, pues solo se perdona lo que se sabe que sucedió. La discusión sobre la verdad apunta a determinar cómo ésta se construye dentro de los procesos de justicia transicional. Tradicionalmente el espacio de la verdad ha sido reservado a las comisiones de la verdad y, con mucha frecuencia, cuando en un proceso de justicia transicional se hace uso prevalente de estas comisiones, se reduce el uso de la justicia y del proceso penal.

El proceso penal es un espacio en el cual la verdad se construye de manera autoritativa por el juez, luego de escuchar los relatos propuestos por las partes. En este proceso de construcción de la verdad adquiere mayor relevancia la evidencia empírica, esto es, la prueba científica, que el testimonio. ${ }^{108}$ Como consecuencia de los abusos producidos por el proceso de tipo inquisitivo, el testimonio como prueba principal, y sobre todo la confesión del procesado, pierde peso para determinar el sentido de la sentencia, pues de ese modo se evita la consecución de confesiones o testimonios por medios no autorizados. ${ }^{109}$

Los procesos de paz en Colombia se han desarrollado con frecuencia olvidando a las víctimas. No existían procesos colectivos de reparación y mucho menos

107 Benavides, Farid, Blanca Camps, y Oscar Mateos. «Los retos de la Justicia Transicional en las nuevas transiciones: un estado de la cuestión a partir de los casos de Colombia, Marruecos y Sierra Leona.» Revista de Relaciones Internacionales de la UAM No. 38, 2018.

108 Haack, Susan. Evidence Matters. Science, Proof, and Truth in the Law. Cambridge: Cambridge University Press, 2014.

109 Sin embargo, en los procesos de justicia transicional y en especial en las políticas de la memoria el testimonio de las víctimas directas es escuchado con atención y tiene un valor superior por ser el relato de un sobreviviente. Los testimonios pueden ser producidos de diversas formas, pues puede presentarse como un relato descriptivo, como en el caso de Primo Levi; o puede ser un relato novelado, pero a partir de hechos reales presenciados directamente por su autor, como es el caso de Jorge Semprún. En todo caso, el impostor que falta a la verdad sobre su condición de víctima directa, como en el caso de Enric Marco, no es un testigo fiable y por tanto no es uno que sea aceptado en los procesos de producción de verdad y de memoria. 
140 El archivo y el testigo. Un análisis de la relación entre memoria y justicia a partir del caso colombiano -

Farid Samir Benavides Vanegas

políticas de la memoria. Es sólo con el proceso de desmovilización de las AUC que se comienza a hablar de justicia transicional en Colombia y que se establece un proceso orientado a obtener la confesión de los victimarios a cambio de una pena alternativa. Al contrario que en el proceso penal ordinario, en el proceso creado por la ley 975 de 2005, conocida como Ley de Justicia y Paz, la determinación de la verdad gira alrededor de las confesiones de los victimarios. ${ }^{10}$ Con poca frecuencia se acude a las víctimas, pues su participación en el proceso solo se hace al final del juicio, durante el incidente de reparación, y solo con el fin de determinar el daño sufrido para determinar la reparación a que tienen derecho. Pero los relatos de los victimarios solo aportan una parte de la verdad. En especial porque con frecuencia son relatos justificatorios o heroicos, que no suponen un reconocimiento del daño causado a las víctimas. Estos relatos/testimonios resultaron estratégicos, pues apuntaban a reconocer una responsabilidad disminuida y a controlar las acciones del gobierno de Álvaro Uribe mediante la amenaza de contar los supuestos nexos de las autoridades del gobierno con los grupos paramilitares. En ese sentido los testimonios son perturbadores, y no conducen a la dignificación de las víctimas.111

El proceso de justicia y paz ha proporcionado algunos testimonios de los jefes de los grupos paramilitares. En estos se desvirtúan los testimonios rendidos ante la jurisdicción ordinaria, en donde se desarrollaban diferentes estrategias para distorsionar la verdad y para presentar un relato diferente de las cosas, lo que los autores de una investigación realizada en Medellín (Antioquia) denominaron prácticas de impunidad y que definen como "un conjunto de acciones que, al estar dirigidas a impedir o distorsionar el castigo judicial a la criminalidad burocrática e irregular contrainsurgente, se constituyen en afirmación del poder en el marco de una situación conflictiva".112 Estas prácticas tienen diferentes estrategias: en primer lugar se dan prácticas administrativas como el traslado de proceso, la destitución de funcionarios, la centralización selectiva de procesos; procesales, como la modificación de la calificación de los delitos, la desestimación arbitraria de los acervos probatorios, la destrucción de pruebas; políticas, como la ausencia

110 Aranguren Romero, Juan Pablo. Managing Testimony and Administrating Victims. Colombia's Transitional Scenario under the Justice and Peace Act. New York: Palgrave Macmillan, 2017.

111 Payne, Leigh. Unsettling Accounts: Neither Truth Nor Reconciliation in Confessions of State Violence. Durham: Duke University Press, 2007. Tsutsul, Kiroteru. "The Trajectory of Perpetrator's Trauma: Mnemonic Politics around the Asia-Pacific War in Japan.» Social Forces Vol. 87 No. 3 , March 2009: $1289-1422$.

112 AAVV. Memoria de la impunidad en Antioquia. Lo que la justicia no quiso ver frente al paramilitarismo. Medellín: IPC - Corporación Jurídica Libertad, 2010. 
de investigación a altos funcionarios del Estado, omisiones en la formulación de conflictos de competencias, la selección política de funcionarios judiciales; y criminales, como la celebración de acuerdos clandestinos de colaboración con los grupos criminales, la utilización de testigos falsos, y las amenazas o asesinatos de funcionarios judiciales. ${ }^{113}$

Los testimonios judiciales son importantes, pues se producen en uno de los lugares de la memoria de los que hablaba Pierre Nora. En ellos "se ejerce un poder ritualizado que le permite a la sociedad reconocerse".114 Si bien la decisión judicial establece con criterio autoritativo la verdad del pasado, en todo caso es el producto de una interpretación del pasado en conjunto con las normas que lo enmarcan y por ello es un ejercicio particular de producción de verdad y de memoria. Como lo señala el Centro de Memoria Histórica, la verdad del proceso de justicia y paz es la verdad de sus atrocidades, pero no tanto la de los discursos que legitimaron el fenómeno paramilitar ni los órdenes regionales construidos entre el consenso y la coerción. Se visibiliza sobre todo la actividad criminal, pues al fin de cuentas se trata de un proceso penal. ${ }^{115}$ Para los redactores del informe del Centro de Memoria Histórica:

En cuanto mecanismo de justicia transicional, el proceso de justicia y paz, además de excepcional y extraordinario, debe ser una suerte de teatro pedagógico orientado hacia la transformación identitaria de la sociedad. En un sentido subjetivo y performativo, el proceso de Justicia y Paz debe cumplir su función pedagógica a través de re-presentar de cara a las víctimas y a la sociedad en general, la dignificación y exaltación de las víctimas y la humillación del victimario. El proceso de Justicia y Paz es, con ello, una suerte de trituradora de identidades. ${ }^{116}$

Para el Centro de Memoria Histórica, la calificación jurídica de los hechos es importante pues, citando a Mark Ossiel, considera que de ese modo se caracteriza de una manera determinada el pasado y se orienta la historia que se va a contar. Sin embargo, en un país con tantos delitos tipificados -que se ha denominado inflación legislativa- esta es una tarea complicada pues muchos tipos penales son posibles y al final la discusión termina centrada más en la calificación que en el hecho en

113 Ibíd.

114 Ibíd.

115 Ibíd.

116 Ibíd. 
sí mismo. ${ }^{117}$ Los autores del informe sobre el proceso de justicia y paz critican la calificación de concierto para delinquir -usada para caracterizar a las organizaciones no rebeldes- pues homogeniza lo que es diferente. Sin embargo, esta es una crítica que se puede hacer extensiva a todos los tipos penales, pues obviamente cada realidad es distinta y por ello el tipo penal solo recoge los rasgos más generales. ${ }^{118}$

\section{Testimonios Perturbadores}

En los procesos de justicia transicional y en los procesos de memoria histórica el testimonio de las víctimas y de los victimarios es central y en muchos casos el valor del testimonio está dado única y exclusivamente por el hecho de ser un "testigo" directo de los hechos. El valor acordado a los testimonios de Primo Levi, Elie Wiesel, Jorge Semprún, Jean Amery, deriva de su carácter como víctimas y como testigos directos. Pero no en todos los casos escuchamos el relato de las víctimas, sino que también damos espacio a los de los victimarios. Escucharlos nos permite, en ocasiones, darles sentido a los hechos victimizantes y explicarlos, aunque no necesariamente comprenderlos. Estos hechos pueden ser presentados de diferentes maneras, tal y como lo explicara Tsutsui, al mostrar que se pueden asumir una actitud negadora de los hechos, una justificatoria, una que desplaza la culpa a la víctima, etc. ${ }^{119}$

En el prólogo a la versión en español del libro de Payne se destaca la tipología construida por ella para analizar los diferentes testimonios: el arrepentido (Scilingo); la memoria heroica (Astiz); el sádico (Romo); la memoria negadora (Contreras); la confesión novelada (Correa Cabral); el testimonio amnésico (Benzien); y la confesión delatora (De Kock) y a lo que agrega Uprimny, prologuista del libro, la confesión por ausencia, esto es, el silencio de los victimarios. ${ }^{120}$

El texto de Payne muestra que frente a los testimonios hay por lo menos dos posiciones: quienes prefieren silenciarlos y quienes le dan un valor terapéutico y reconciliador. Payne critica a quienes les otorgan a estos testimonios virtudes terapéuticas y considera que no

117 Ibíd.

118 Ibíd.

119 Tsutsul, Kiyoteru. «The Trajectory of Perpetrator's Trauma: Mnemonic Politics around the Asia-Pacific War in Japan.» Social Forces Vol. 87 No. 3 , March 2009: 1289 - 1422.

120 Uprimny, Rodrigo. "Introducción.» En Testimonios Perturbadores. Ni verdad ni reconciliación en las confessiones de violencia del Estado, de Leigh Payne. Bogotá: Uniandes / Ideas para la Paz, 2009. 
...suelen ser la verdad de lo ocurrido, puesto que son siempre versiones interesadas, que ocultan ciertos aspectos, redimensionan otros, buscan justificar las atrocidades o minimizan su impacto. Incluso, las versiones que pretenden ser más honestas, aquellas de los arrepentidos, no escapan de esas limitaciones. Y por ello las confesiones de los victimarios no cierran el debate sobre lo ocurrido, ni generan consenso, ni tranquilizan a las víctimas 0 a sus familias. ${ }^{121}$

Sin embargo, para Payne, estos testimonios no pueden ser prohibidos. Desde una concepción deliberativa de la democracia sugiere que la discusión pública sobre lo ocurrido no tiene por qué desestabilizar a la democracia; todo lo contrario, al hacerse en público garantiza que los perpetradores se vean obligados a dar razones y sobre todo impide que nieguen sin más la comisión de esos actos atroces. Uprimny destaca el valor del análisis de Payne para Colombia, pues las confesiones han conducido a un mayor conocimiento del fenómeno paramilitar. Sin embargo, este conocimiento no ha producido la reconciliación y sí ha servido para un uso estratégico de los relatos. Pese a esas limitaciones, Uprimny considera positivo que se tengan estas confesiones y que se conozca un poco más de los crímenes cometidos por los paramilitares.

Payne lo explica de la siguiente manera:

Las confesiones de los perpetradores alteran a los que las escuchan, pues, en algunos casos, por primera vez se enteran de detalles estremecedores y espeluznantes. Estas confesiones perturban, o rompen, el silencio impuesto sobre el pasado por aquellas fuerzas dentro de las sociedades democráticas que anhelan dejar el pasado y cerrar la página. Estas confesiones, sin embargo, no revelan necesariamente verdades sobre el pasado. Se trata de simples informes, explicaciones y justificaciones de un comportamiento por fuera de lo normal, o de versiones personales sobre el pasado. $^{122}$

Para Payne, después de un periodo de violaciones masivas a los derechos humanos es imposible tener un relato unificado del pasado. Sin embargo, ella considera que debe darse una coexistencia contenciosa entre los diferentes relatos, en donde las diferentes versiones debaten continuamente sobre el significado de lo

121 Ibíd.

122 Payne, Lelgh. Unsettling Accounts: Neither Truth Nor Reconciliation in Confessions of State Violence. Durham: Duke University Press, 2007. 
ocurrido. Pero ese debate estimula la participación y la discusión crítica y todo ello contribuye al fortalecimiento de la democracia. ${ }^{123}$ Payne destaca la importancia del debate público, precisamente para que no quede como única versión del pasado la de los victimarios, tal y como ocurre en el caso colombiano. Sin embargo, en todo caso, se llama la atención para no caer en la trampa de pensar que existen múltiples versiones válidas del pasado, solo que al comienzo de la transición ellas existirán y corresponde a la justicia y a las disciplinas históricas establecer con autoridad qué fue lo que efectivamente sucedió. Para Payne, los perpetradores y sus audiencias compiten por el poder político. Destaca la importancia de tener en cuenta cómo se hace la narración, dónde y cuándo. Muestra cómo tipos particulares de instituciones puede generar más de un tipo particular de confesión: comisiones de la verdad que generan remordimiento o procesos judiciales que provocan desmentidos. ${ }^{124}$

Los testimonios de los perpetradores suponen una reinvención de su pasado. Se usan para ajustarse a un momento político en particular o para satisfacer una necesidad personal. Estos testimonios incluyen remordimiento, heroísmo, sadismo, negación, silencio, ficción y mentiras, amnesia y traición. ${ }^{125} \mathrm{Al}$ lado de los actores y de los guiones utilizados, Payne analiza los escenarios en que los testimonios de los perpetradores se dan. Con frecuencia el espacio de representación son los medios de comunicación, y frente a ellos los perpetradores actúan (perform) su confesión. Sin embargo, no basta con el relato del perpetrador, pues también se requiere una comunidad de interpretación que le dé sentido a lo que dice.126 Los auditorios reaccionan desde una de las cinco posiciones que la autora postula: cínica, traumática, curativa, de retribución y de redención.

Al analizar el enfoque curativo Payne destaca sus limitaciones, en tanto impone un peso excesivo sobre las víctimas y los sobrevivientes. Por el contrario, quienes abogan por un modelo retributivo consideran que los juicios son curativos pues restauran la igualdad de las personas frente a la justicia y sientan un precedente que debe prevenir futuras violaciones: "los juicios, aún más, han sido pensados para enseñar una lección. Demuestran igualdad ante la ley. Las actividades ilegales de

123 Uprimny, Rodrigo. "Introducción.» En Testimonios Perturbadores. Ni verdad ni reconciliación en las confessiones de violencia del Estado, de Leigh Payne. Bogotá: Uniandes / Ideas para la Paz, 2009.

124 Ibíd.

125 Ibíd.

126 Воотн, W. James. "The unforgotten: Memories of Justice.» The American Political Science Review Vol. 95 No. 4 (December), 2001: 777 - 791. Bоoтн, James. Communities of Memory: on witness, identity and justice. Ithaca: Cornell, 2006. 
todos los ciudadanos, incluidas las fuerzas políticas de la élite, serán juzgadas por las leyes del país". ${ }^{27}$ Sin embargo, el escenario del enfoque retributivo es un escenario muy alejado del público como para que se produzcan los efectos deseados por los perpetradores. Por ello suelen acompañar sus relatos sobre el pasado en el juicio, con relatos en los medios de comunicación, con el fin de dotar de una audiencia más amplia a su presentación. Payne está de acuerdo en que estos relatos, por perturbadores que sean, no sean objeto de censura, pues ellos contribuyen de varias maneras a la consolidación de la democracia. Esta autora destaca cinco aspectos en los que los relatos perturbadores contribuyen a lo que ella denomina la coexistencia contenciosa:

- Los temas de violencia del Estado no pueden quedar por fuera de la discusión pública

- Las democracias se ven mejor servidas si acogen estos asuntos

- Estas representaciones dramáticas ponen en práctica a la democracia

- El debate contencioso trastoca las relaciones de poder en la sociedad, lo que puede conducir a resultados más democráticos.

- La ganancia extra de la contención es llegar a resultados más democráticos. ${ }^{128}$

Al analizar las confesiones heroicas, Payne muestra su valor para la discusión democrática. El hecho que los perpetradores se vanaglorien de su pasado, si bien puede tener un efecto traumático en las víctimas -sobre todo si es una confesión sádica- ofrece nuevos elementos para la discusión, pues los perpetradores ya no pueden eludir su responsabilidad,

...la atrocidad queda asociada a perpetradores específicos (...) la responsabilidad también puede desarticular los polos de la memoria. Aquellos que previamente habían apoyado el régimen, interpretando el silencio como inocencia y creyendo las negaciones, deben enfrentarse al hecho de si continúan apoyando al régimen y sus ideales una vez que conocen la verdad sobre la violencia. Algunos deciden que no pueden. Se unen a aquellos que condenan las prácticas pasadas y comparten, incluso así sea de manera pasiva, el respeto por los Derechos Humanos y la justicia. ${ }^{129}$

127 Payne, Leigh. Unsettling Accounts: Neither Truth Nor Reconciliation in Confessions of State Violence. Durham: Duke University Press, 2007.

128 Ibíd.

129 Ibíd. 


\section{Conclusión: ¿testimonios perturbadores y archivos tranquilizadores?}

El proceso penal produce una verdad resultado de la confrontación entre las partes. Es una verdad con el mismo derecho que la verdad histórica y con su misma validez. Dentro de los procesos transicionales la verdad es con frecuencia objeto de las comisiones de la verdad, pues en ellas los relatos son enfrentados y el relato final debe ser producto del consenso de todas las partes. En el proceso de Justicia y Paz de Colombia éste no es el caso. La verdad que se produce es una verdad solamente de los victimarios y encontramos pocos espacios para escuchar el relato de las víctimas.

Pese al carácter perturbador de estos testimonios, Leigh Payne les da valor pues contribuyen a lo que ella denomina una coexistencia contenciosa. Sin embargo, en el caso colombiano no parece ser así. Los testimonios relatan los crímenes de los paramilitares, pero siempre como parte de un relato justificador. Esto lo vemos en las versiones libres y en los textos autobiográficos de los jefes paramilitares. Los jefes de estos grupos criminales dan su propia versión de la verdad, pero no se abren instancias para su confrontación. Es importante que estos relatos sean confrontados y cuestionados y, sobre todo, que se desmonten sus mentiras justificatorias, que al final quede claro el acto arbitrario y gratuito de sus crímenes.

El proceso de Justicia y Paz ha contribuido en parte, aunque no de manera completa, a desmontar algunos mitos, como la existencia de un grupo unificado bajo el mando de Carlos Castaño llamado Autodefensas Unidas de Colombia AUC, pero dada su naturaleza los mitos restantes quedan vigentes. La verdad perturba no por lo que dice, sino por lo que se oculta, por el daño simbólico que se quiere seguir causando a las víctimas.

La memoria del pasado debe construirse a partir de los testimonios, de los documentos oficiales y no oficiles, de los relatos de las víctimas y de sus victimarios. Pero todo ello debe darse dentro de un espacio en donde todos esos instrumentos de la memoria sean objeto de crítica. No se trata simplemente de recordar, ni de abusar de la memoria del pasado. Se trata de recordar lo que efectivamente pasó, para poder sentar las bases para la construcción de un futuro mejor. En ese sentido, la memoria y sus instrumentos con como la cara de Jano, con una parte mirando hacia el pasado y la otra hacia el futuro. Pero también comparten los elementos del Ángel de la Historia de Benjamin, mirando el horror del pasado, sabiendo que el presente y el futuro derivan de él. ${ }^{130}$ 


\section{Bibliografía}

AAVV. Justicia y Paz. Los silencios y los olvidos de la verdad. Bogotá: Centro de Memoria Histórica, 2012.

AAVV. Justicia y Paz: ¿Verdad judicial o verdad histórica? Bogotá: Centro Nacional de Memoria Histórica, 2012.

AAVV. Memoria de la impunidad en Antioquia. Lo que la justicia no quiso ver frente al paramilitarismo. Medellín: IPC - Corporación Jurídica Libertad, 2010.

AAVV. Recordar para Reparar. Las masacres de Matal de Flor Amarillo y Corocito en Arauca. Bogotá: Centro de Memoria Histórica, 2014.

Adorno, Theodor. «La educación después de Auschwitz.» En Crítica cultural y sociedad, de Teodoro Adorno. Madrid: Sarpe, 1984.

Agamben, Giorgio. Lo que queda de Auschwitz: el archivo y el testigo. Homo Sacer II. Valencia: Pre - Textos, 2010.

Aguilar Fernández, Paloma. Políticas de la memoria y memorias de la política. El caso español en perspectiva comparada. Madrid: Alianza Editorial, 2008.

Aller Montaño, Eugenia; Crenzel, Emilio (eds). Las luchas por la memoria en América Latina. Historia reciente y violencia política. Madrid: Iberoamericana, 2016.

Amery, Jean. Más allá de la culpa y de la expiación: tentativas de superación de una víctima de la violencia. Valencia: Pre-Textos, 2004.

Aranguren Romero, Juan Pablo. Managing Testimony and Administrating Victims.

Colombia's Transitional Scenario under the Justice and Peace Act. New York: Palgrave Macmillan, 2017.

Arthur, Palge. «How 'Transitions' Reshaped Human Rights: A Conceptual History of Transitional Justice.» Human Rights Quarterly 31, 2009: 321 - 367.

Ash, Timothy Garton. "The Truth About Dictatorship.» The New York Review of Books, 1998.

Augé, Marc. Las formas del olvido. Barcelona: Gedisa, 1998.

Augstein, Franziska. Lealtal y traición. Jorge Semprún y su siglo. Barcelona: Tusquets, 2010.

Baer, Alejandro. Holocausto, Recuerdo y Representación. Madrid: Losada, 2006.

Press, 2008. Benjamin, Walter. Iluminaciones. Madrid: Taurus, 2018. Mate, Manuel Reyes. La Razón de los Vencidos. Barcelona: Anthropos, 2013. 
148 El archivo y el testigo. Un análisis de la relación entre memoria y justicia a partir del caso colombiano -

Farid Samir Benavides Vanegas

Bass, Gary J. "Jus Post Bellum.»Philosophy and Public Affairs 32 (4), 2004: 384 $-412$.

Bedoya Sierra, Luis Fernando. La prueba en el proceso penal colombiano. Bogotá: Fiscalía General de la Naciòn, 2008.

Benavides, Farid. «iTiene futuro la justicia transicional?» Revista Derecho Penal No. 58, 2017: 5 - 44.

Benavides, Farid, Blanca Camps y Oscar Mateos. "Los retos de la Justicia Transicional en las nuevas transiciones: un estado de la cuestión a partir de los casos de Colombia, Marruecos y Sierra Leona.» Revista de Relaciones Internacionales de la UAM No. 38, 2018.

Benjamin, Walter. Iluminaciones. Madrid: Taurus, 2018.

Bergall, Roberto. Memoria colectiva como deber social. Barcelona: Anthropos, 2010.

Booth, James. Communities of Memory: on witness, identity and justice. Ithaca: Cornell, 2006.

Bоoтн, W. James. "The unforgotten: Memories of Justice.» The American Political Science Review Vol. 95 No. 4 (December), 2001: 777 - 791.

Browning, Christopher. Collected Memories: Holocaust History and Postwar Testimony. Madison: University of Wisconsin Press, 2003.

Bustamante Rúa, Mónica y Diego Palomo Vélez. «La presunción de inocencia como regla de juicio y el estándar de prueba de la duda razonable en el proceso penal. Una lectura desde Colombia y Chile.» lus et Praxis vol. 24 No. 3, 2018: 651 - 692.

Bustos, Gerardo. "La irrupción del testimonio en América Latina: intersecciones entre historia y memoria.» Historia Crítica No. 40 Dossier Memoria, Historia y Testimonio en América Latina, Enero - Abril 2010: 10 - 19.

Calveiro, Pilar. "Los usos políticos de la memoria." En Sujetos sociales y nuevas formas de protesta, de Gerardo, comp Caetano. Buenos Aires: CLACSO, 2006.

Cercas, Javier. El Impostor. Barcelona: Penguin Random House, 2014.

Cercas, Javier Cercas. "La tiranía de la memoria.» El País, 2 de enero de 2008: 1.

Chiarlon, Sergio. "La verdad tomada en serio.» Revista Eletrônica de Direito Processual - REDP (Mayo-Agosto), 2018: 184 - 199.

Decastro González, Alejandro. «Admisibilidad y valor probatorio de las declaraciones anteriores del testigo.» Revista Internacional de Derecho Penal Contemporáneo, 2009: 37 - 94. 
DonÁ, GioRGiA. ""Situated Bystanderhip" during and after the Rwandan Genocide.» Journal of Genocide Research vol. 20 No. 1, 2018: 1 - 19.

FABRI, Silvina M. "Lugares de memoria y marcación territorial: sobre la recuperaciòn de los centros clandestinos de detenciòn en Argentina y los lugares de memoria en España.» Cuadernos de Geografía vol.22 No. 1 (Enero - Junio), 2013: 93 - 108.

Feld, Claudia. Del estrado a la pantalla: las imagines del juicio a los excomandantes en Argentina. Madrid: Siglo XXI, 2002.

Ferrer Beltrán, Jordo. Prueba y Verdad en el Derecho. Barcelona: Marcial Pons, 2002.

Ferrer, Jord y Daniel Mendonca. «Introducción.» En Verifobia. Un diálogo sobre prueba y verdad, de Michele Taruffo. Lima: Palestra Editores, 2012.

Finkelstein, Norman. The Holocaust Industry: Reflections on the Exploitation of Jewish Suffering. London: Verso, 2015.

Finkielkraut, Alain. La memoria vana. Del crimen contra la humanidad. Barcelona: Anagrama, 1990.

Galán Vélez, Francisco Vicente. «Verdad Pragmática y Verdad Consensual en Habermas; una lectura lonargeneana.» Universitas Philosophica Vol. 31 No. 62 (enero-junio), 2014 : $113-145$.

Ginzburg, Carlo. El Queso y los Gusanos. El cosmos según un molinero del siglo XVI. Barcelona: Muchnik, 1982

González Lagier, Daniel. Questio Facti. Ensayo sobre prueba, causalidad y acción. Bogotá: Temis, 2005.

Haack, Susan. Evidence Matters. Science, Proof, and Truth in the Law. Cambridge: Cambridge University Press, 2014.

HaAck, Susan. "Of Truth, in Science and Law.» 73 Brooklyn Law Review, 2008: 985 $-1008$

HaAck, Susan. "Truth, Truths, "Truth", and "Truths" in the Law.» 26 Harvard Journal of Law and Public Policy, 2003: 17 - 21.

Habermas, Jünger. Facticidad y Validez. Barcelona: Trotta, 1998.

Habermas, Jünger. El Pensamiento Postmetafísico. Madrid: Taurus, 1990.

Habermas, Jünger. Teoría de la Acción Comunicativa. Madrid: Taurus, 1987.

Hinton, Alexander Laban. Man or Monster?: The Trial of a Khmer Rouge Torturer. Durham: Duke University Press, 2016. 
Hinton, Alexander Laban. The Justice Facade. Trials of Transition in Cambodia. Oxford: Oxford University Press, 2018.

Jara, Daniela. Children and the Afterlife of State Violence. Memories of Dictatorship. New York: Palgrave Macmillan, 2016.

Jelin, Elizabeth. Los trabajos de la memoria. Buenos Aíres: Siglo XXI, 2002.

Labany, Jo. "El cine como memoria. La memoria del cine.» En Plan Rosebud. Sobre imágenes, lugares y políticas de la memoria, de María (ed) Ruido, 471 - 484. Santiago de Compostela: Xunta de Galicia/Centro Galego de Arte Contemporánea, 2008.

Leebaw, Bronwyn Anne. "The Irreconcilable Goals of Transitional Justice.» Human Rights Quarterly vol. 30 No. 1, February 2008: 95 - 118.

LevI, Primo. Trilogía de Auschwitz. Barcelona: El Aleph, 2005.

Longman, Timothy. Memory and Justice in Post-Genocide Rwanda. Cambridge: Cambridge University Press, 2017.

Malem, Jorge. El error judicial y La formaciòn de los jueces. Madrid: Fundación Coloquio Jurídico Europeo, 2009.

Mate, Manuel Reyes. La Razón de los Vencidos. Barcelona: Anthropos, 2013.

Mate, Manuel Reyes. Tratado de la Injusticia. Barcelona: Anthropos, 2011.

Mosés, Stéphane. The Angel of History: Rosenzweig, Benjamin, Scholem. Stanford: Stanford University Press, 2008.

Munté, Rosa Auria. La ficción sobre el Holocausto: silencio, límites de representaciòn y popularización en la novena Everything is Illuminated de Jonathan Safran Foer. Tesis Doctoral. Barcelona: Universidad Ramón Llull, 2011.

Nicolas, Juan Antonio y María José (eds) Frapolu. Teorías Contemporáneas de la Verdad. Madrid: Tecnós, 2012.

Olick, Jefrerey K. y Joyce Robbins. "Social Memory Studies: from "collective memory" to the historical sociology of mnemonic practices.» Annual Sociological Review Nro. 24, 1998: 105 - 140.

Olick, JefrReY K. "Memory and the Nation: continuities, conflicts, and transformations.» Social Science History Vol. 22 No. 4, Winter 1998: 377 - 387.

Ortega-Ruíz, luis German y Juan Pablo García Miranda. "La verdad en la justicia transicional.» lusta No. 50 (Enero - Junio ), 2019: 39 - 63. 
Páez, Andrés. «La prueba testimonial y la epistemología del testimonio.» Isonomía 40, Abril 2014: 95 - 118.

Payne, Lelgh. Unsettling Accounts: Neither Truth Nor Reconciliation in Confessions of State Violence. Durham: Duke University Press, 2007.

Pérez Tapias, José Antonio. "Verdad de la Justicia y Poder de la Mentira.» En El valor de la verdad. Hermenéutica, semántica, política, de Juan Antonio Nicolás y María José (eds) Frapolli, 479 - 538. Granada: Comares, 2000.

Ricoeur, Paul. La lectura del tiempo pasado: memoria y olvido. Madrid: Universidad Autónoma de Madrid, 1999.

RiefF, David. Elogio del Olvido. Barcelona: Debate, 2016.

RobBen, Antonius C.G.M. Argentina Betrayed. Memory, mourning and accountability. Philadelphia: University of Pennsylvania Press, 2018.

Rodríguez Serpa, Ferney Asdrúbal, Neliniño Bolaño Miranda y Gloria María Algarín HeRRERA. «De la valoraciòn racional de la prueba en la verdad procesal a la teoría de la probabilidad preponderante.» Jurídicas CUC vol. 14 No. 1, 2018: 259 - 286.

Rosenberg, Alvin H. The end of the holocaust. Bloomington: Indiana University Press, 2011.

Rosón, María y R. Lucas Platero. «Fantasmas, Género, Memoria y Políticas Públicas en la Reciente Historia Española.» En Polítiques de Memòria, Gènere i Ciutat, de Maria de la Fuente (coord), 8 - 34. Barcelona: Institut de Ciències Polítiques i Socials, 2017.

Sanabria Torres, Luisa Paola. "Investigación social para la paz en Colombia: entre la verdad histórica y la prueba judicial.» En El proceso de paz en Colombia. Disertaciones alrededor de una historia, de Dory Luz Gonzalez Hernández. Bogotá: Los Libertadores, 2016.

Sánchez-Biosca, Vicente. Cine y Guerra Civil. Del mito a la memoria. Madrid : Alianza, 2006.

Sánchez, Gonzalo. "Tiempos de memoria, tiempos de víctimas." Análisis Político 63 (Mayo - Agosto), 2008: 3 - 21.

Taruffo, Michele. La prueba de los hechos. Madrid: Trotta, 2002.

Taruffo, Michele. "Proceso y Verdad en la Transición.» Derecho y Sociedad No. 50, 2018: 295 - 306. 
Taruffo, Michele. Simplemente la verdad. El juez y la construcción de los hechos. Barcelona: Marcial Pons, 2010.

Todorov, Tzvetan. Memoria del mal, tentación del bien: indagación sobre el siglo XX. Barcelona: Editorial Península, 2002.

Tsutsul, Kiroteru. «The Trajectory of Perpetrator's Trauma: Mnemonic Politics around the Asia-Pacific War in Japan.» Social Forces Vol. 87 No. 3 , March 2009: 1289 $-1422$.

Uprimny, Rodrigo. «Introducción.» En Testimonios Perturbadores. Ni verdad ni reconciliación en las confessiones de violencia del Estado, de Leigh Payne. Bogotá: Uniandes / Ideas para la Paz, 2009.

Vera Sánchez, Juan Sebastián. "Cuatro mitos sobre la justicia retributiva como mecanismo de justicia transicional.» 32 American University International Law REview 469, 2016 - 2017: 469 - 499.

WeIGend, Thomas. "Is the criminal process about truth? A German perspective.» 26 Harvard Journal of Law and Public Policy , 2003.

WeIGEND, Thomas. «Should we search for the truth? and, who should do it?» N.C.J. International Law \& Com. Reg. XXXVI, 2010.

Wiesel, Elie. Los Judíos del Silencio. Barcelona: Paidós, 1986. 